\title{
PDE-4 Inhibition Rescues Aberrant Synaptic Plasticity in Drosophila and Mouse Models of Fragile X Syndrome
}

\author{
Catherine H. Choi ${ }^{1,2,3}$ Brian P. Schoenfeld, ${ }^{1,4 *}$ Eliana D. Weisz, ${ }^{4 \star}$ Aaron J. Bell, ${ }^{1,4}$ Daniel B. Chambers, ${ }^{5}$ \\ 이 Joseph Hinchey, ${ }^{1}$ Richard J. Choi, ${ }^{1}$ Paul Hinchey, ${ }^{1}$ Maria Kollaros, ${ }^{1}$ Michael J. Gertner, ${ }^{6}$ Neal J. Ferrick, ${ }^{1,4}$ \\ Allison M. Terlizzi, ${ }^{1}{ }^{\oplus}$ Nicole Yohn, ${ }^{4}$ Eric Koenigsberg, ${ }^{1}$ David A. Liebelt, ${ }^{1}$ R. Suzanne Zukin, ${ }^{6}$ Newton H. Woo, ${ }^{7}$ \\ Michael R. Tranfaglia, ${ }^{8}$ Natalia Louneva, ${ }^{9}$ Steven E. Arnold, ${ }^{9}$ Steven J. Siegel, ${ }^{9}$ Francois V. Bolduc, ${ }^{5}$ \\ Thomas V. McDonald, ${ }^{1}$ Thomas A. Jongens, ${ }^{4}$ and Sean M. J. McBride ${ }^{1,4,9}$ \\ ${ }^{1}$ Section of Molecular Cardiology, Departments of Medicine and Molecular Pharmacology, Albert Einstein College of Medicine, Bronx, New York 10461, \\ ${ }^{2}$ Department of Medicine, Lehigh Valley Health System, Allentown, Pennsylvania 18103, ${ }^{3}$ Department of Dermatology, Drexel University College of \\ Medicine, Philadelphia, Pennsylvania 19107, ${ }^{4}$ Department of Genetics, University of Pennsylvania School of Medicine, Philadelphia, Pennsylvania 19104, \\ ${ }^{5}$ Department of Pediatrics, Center for Neuroscience, University of Alberta, Edmonton, Alberta T6G 2N8, Canada, ${ }^{6}$ Dominick P. Purpura Department of \\ Neuroscience, Albert Einstein College of Medicine, Bronx, New York 10461, ${ }^{7}$ Division of Anesthesia, Analgesia and Addiction Products, Office of Drug \\ Evaluation II, OND/CDER/FDA, Silver Spring, Maryland 20993, ${ }^{8}$ FRAXA Research Foundation, Newburyport, Massachusetts 01950, and ${ }^{9}$ Department of \\ Psychiatry, University of Pennsylvania School of Medicine, Philadelphia, Pennsylvania 19104
}

Fragile X syndrome (FXS) is the leading cause of both intellectual disability and autism resulting from a single gene mutation. Previously, we characterized cognitive impairments and brain structural defects in a Drosophila model of FXS and demonstrated that these impairments were rescued by treatment with metabotropic glutamate receptor (mGluR) antagonists or lithium. A well-documented biochemical defect observed in fly and mouse FXS models and FXS patients is low cAMP levels. cAMP levels can be regulated by mGluR signaling. Herein, we demonstrate PDE-4 inhibition as a therapeutic strategy to ameliorate memory impairments and brain structural defects in the Drosophila model of fragile X. Furthermore, we examine the effects of PDE-4 inhibition by pharmacologic treatment in the fragile X mouse model. We demonstrate that acute inhibition of PDE- 4 by pharmacologic treatment in hippocampal slices rescues the enhanced mGluR-dependent LTD phenotype observed in FXS mice. Additionally, we find that chronic treatment of FXS model mice, in adulthood, also restores the level of mGluR-dependent LTD to that observed in wild-type animals. Translating the findings of successful pharmacologic intervention from the Drosophila model into the mouse model of FXS is an important advance, in that this identifies and validates PDE-4 inhibition as potential therapeutic intervention for the treatment of individuals afflicted with FXS.

Key words: cAMP; Drosophila; fragile X; memory; mouse; phosphodiesterase 4

\section{Introduction}

Fragile X syndrome (FXS) is the most common inherited monogenetic disorder resulting in intellectual disability and autism

\footnotetext{
Received March 19, 2012; revised 0ct. 20, 2014; accepted Nov. 8, 2014.

Author contributions: C.H.C., E.D.W., M.R.T., S.E.A., S.J.S., F.V.B., T.V.M., T.A.J., and S.M.J.M. designed research; C.H.C., B.P.S., E.D.W., A.J.B., D.B.C., J.H., R.J.C., P.H., M.K., M.J.G., N.J.F., A.M.T., N.Y., E.K., D.A.L., N.H.W., N.L., T.A.J., and S.M.J.M. performed research; C.H.C., E.D.W., T.A.J., and S.M.J.M. analyzed data; C.H.C., R.S.Z., T.A.J., and S.M.J.M. wrote the paper.

This work was supported by the FRAXA Research Foundation to S.M.J.M., C.H.C., and T.A.J.; the National Fragile X Foundation for a summer fellowship award to Eric Koenigsberg; Autism Speaks to T.V.M. and S.M.J.M.; the Albert Einstein College of Medicine National Institutes of Health MSTP Grant R25 MH060490 (Clinical Research Scholars Program in Psychiatry) to S.M.J.M.; and National Institutes of Health Grant GM086902 and DOD-Autism Grant AR1101189 to T.A.J., D.B.C. and F.V.B. were supported by Canadian Institutes for Health Research. E.D.W. was supported by the McMorris Autism Program. We thank Efthimios Skoulakis, Myles Akabas, Thomas Dockendorff, Graham Ellis-Davies, Dan Kelley, Alex Harris, Boris Heifets, Kanji Takahashi, Diana Petit, Randi Hagerman, David Nelson, Elizabeth Berry-Kravis, Peter Davies, Peter Klein, Peter Vanderklish, Eric Klann, and Sumantra Chattarji for critical comments during this project; Mark Bear and Pablo Castillo for advice regarding the electrophysiology methods; Charles Rubin and Susan Horwitz for generously providing space and resources; Melanie Talent for the use of space and equipment; and the Animal Care Facility at Drexel College of Medicine and Albert Einstein College of Medicine, specifically Janet Schulenberg, Andy Nelson, Charlene Glenn, and Carlton Reed, for assistance with animal care.

The authors declare no competing financial interests.
}

spectrum disorders with an occurrence of 1 in 2500 births and results from loss of function mutations in FMR1 (Hagerman 2008). The consequent loss of the gene product, fragile $X$ mental retardation protein (FMRP), is responsible for a constellation of symptoms, including seizures, sleep disorders, anxiety, autism, and mild to severe cognitive impairment (Jacquemont et al., 2007). FMRP is enriched both presynaptically and postsynaptically and is known to associate with and regulate the translation of a number of mRNAs in response to synaptic activity (Jacque-

\footnotetext{
*B.P.S. and E.D.W. contributed equally to this work.
}

Correspondence should be addressed to any of the following: Dr. Thomas V. McDonald, Section of Molecular Cardiology, Department of Medicine and Molecular Pharmacology, Albert Einstein College of Medicine, Bronx, NY 10461, E-mail:tom.mcdonald@einstein.yu.edu; Francois V. Bolduc, Department of Pediatrics, University of Alberta, 1-130DPC, 1130489 Avenue, Edmonton, Alberta T6G2N8, Canada, E-mail: fbolduc@ualberta.ca; Sean M.J. McBride, Department of Psychiatry and Genetics, Perelman School of Medicine, University of Pennsylvania, Genetics Room 10-134, TRC, 10 Floor, 3400 Civic Center Blvd, Bldg 421, Philadelphia, PA 19104-5158, E-mail: smjmcbride@gmail.com; or Thomas A. Jongens, Department of Genetics, University of Pennsylvania, Genetics Room 10-134, TRC, 10 Floor, 3400 Civic Center Blvd, Bldg 421, Philadelphia, PA 19104-5158. E-mail: jongens@mail.med.upenn.edu.

DOI:10.1523/JNEUROSCI.1356-12.2015

Copyright $\odot 2015$ the authors $\quad 0270-6474 / 15 / 350396-13 \$ 15.00 / 0$ 
mont et al., 2007; Akins et al., 2009; Bhogal and Jongens 2010; Krueger and Bear 2011; Gross et al., 2012; Hagerman et al., 2012; McBride et al., 2012; Tessier and Broadie 2012; Darnell and Klann 2013).

A Drosophila model for FXS, based on the loss of dfmr1 expression, displays phenotypes similar to fragile X-related symptoms in humans (Zhang et al., 2001; Dockendorff et al., 2002; Morales et al., 2002; McBride et al., 2005, 2012; Bhogal and Jongens 2010; Tessier and Broadie 2012). Metabotropic glutamate receptor (mGluR) antagonists or lithium treatment can rescue memory and structural brain defects in these flies (McBride et al., 2005). These findings are consistent with the mGluR theory of fragile X (Bear et al., 2004), where enhanced mGluR-mediated signaling leads to pathogenic phenotypes, and point to PDE-4 as another potential therapeutic target within the mGluR signaling cascade (McBride et al., 2005; Bolduc et al., 2008). Interestingly, FXS has been linked to the canonical cAMP-CREB learning and memory pathway (Dudai et al., 1976; Byers et al., 1981; Tully and Quinn 1985; Davis, 1993; Yin et al., 1995; Kandel 2001). Previous studies have demonstrated decreased cAMP levels in cells taken from fragile X patients and that driving FMRP expression in cell culture can increase cAMP levels (Berry-Kravis and Huttenlocher 1992; Berry-Kravis and Sklena 1993; Berry-Kravis et al., 1995; Berry-Kravis and Ciurlionis, 1998). A similar positive-feedback loop between FMRP and cAMP levels was hypothesized and demonstrated in the fly and mouse models of FXS (McBride et al., 2005; Kelley et al., 2007; Kanellopoulos et al., 2012). Indeed, human and animal models appear to have the Fmrl or $d f m r 1$ genes regulated by CREB-mediated gene transcription (Hwu et al., 1997; Impey et al., 2004; Kanellopoulos et al., 2012). cAMP is synthesized by the activity of adenylate cyclase and is degraded by phosphodiesterase (PDE) activity, with PDE-4 being the most abundant cAMP-specific PDE in the brain of flies and mammals (Davis et al., 1989). Herein, the efficacy of pharmacologic inhibition of PDE-4 as a treatment strategy to ameliorate cognitive impairment is characterized in the Drosophila FXS model. In these studies, we find that PDE-4 inhibitor treatment rescues memory in two distinct memory paradigms and also rescues a structural brain defect in the Drosophila model of FXS.

A widely reproduced phenotype in the fragile $\mathrm{X}$ mouse model is exaggerated mGluR-dependent LTD in the CA1 region of the hippocampus (Huber et al., 2002; Hou et al., 2006; Nosyreva and Huber 2006; Choi et al., 2011). This is a critical endophenotype because both LTD and LTP are regarded as cellular models of learning and memory (Kelleher et al., 2004; Malenka and Bear 2004). In this study, we find that both acute application of rolipram to hippocampal slices from Fmr1 KO mice and chronic administration of rolipram at a dose previously demonstrated to inhibit PDE-4 activity in the brain (Barad et al., 1998; Gong et al., 2004) successfully abrogated the enhanced mGluR-dependent LTD phenotype in the Fmr1 KO mice. Our studies demonstrating rescue of relevant phenotypes in the fly and mouse FXS models has identified PDE-4 as a potential therapeutic target for the treatment of patients afflicted with fragile X.

\section{Materials and Methods}

Drosophila strains and drug testing. The Drosophila strains were cultured as in Dockendorff et al. (2002) and McBride et al. (2005). Drugs were obtained from Tocris Bioscience, solubilized according to manufacturer's instructions, and mixed into solid fly food at the appropriate concentration. Vehicle for each drug was added to the appropriate control food for each experiment. For courtship memory, we used $50 \mu \mathrm{M}$ rolipram, $500 \mu \mathrm{M}$ rolipram (high dose), and $20 \mu \mathrm{M}$ Ro-20-1724 in the exper- iments presented. For olfactory classical conditioning, we used $50 \mu \mathrm{M}$ rolipram with $5 \%$ sucrose and $5 \%$ DMSO on a filter paper. Flies were fed overnight after having been starved for $3 \mathrm{~h}$. The flies were trained and tested the next morning. The control consisted of 5\% sucrose and 5\% DMSO.

Behavioral training and testing in the conditioned courtship paradigm. Virgin male flies were collected under anesthesia, and all testing was performed as done previously (McBride et al., 1999, 2005; Choi et al., 2010). Male flies were collected and placed on either vehicle or drug treatment for $10 \mathrm{~d}$ after eclosion. Virgin XX, $y f$ females were collected on the day of eclosion and kept in food vials. Flies were aged in a 12:12 light-dark before behavioral training, and testing was performed during the relative light phase. All male subjects were transferred to fresh control food the day before testing and assigned to random groups for behavioral training and testing. All training and testing was performed blind to genotype and treatment. A courtship index (CI) was calculated following testing as the percentage of total observation time spent courting (Siegel and Hall 1979; McBride et al., 2005). A memory index was calculate as CI naïve - CI trained/CI naive $\times 100$ (Keleman et al., 2007).

Courtship-based immediate-recall memory. Training was performed by placing a naive male with a previously mated female for a $1 \mathrm{~h}$ period. Memory represents a decrease in CI between the naive and post-training testing period. Immediate-recall memory was measured by placing a trained male with a virgin target immediately $(0-2 \mathrm{~min})$ after training for a 10 min courtship test interval.

Courtship-based short-term memory. Short-term memory was measured by placing a trained male in a holding chamber for $60 \mathrm{~min}$ (after a $1 \mathrm{~h}$ training with a previously mated female), then subsequently placing him in a testing chamber with a virgin female target for a 10 min courtship interval.

Statistical analyses. CIs of tested males were subjected to arcsin square root transformations to approximate normal distributions (McBride et al., 1999, 2005). One-way ANOVAs and unpaired Student's $t$ tests were performed on planned comparisons of arcsin square root-transformed data with one-way ANOVA with Sidak's multiple-comparison test to generate critical $p$ values that are shown in the graphs. All statistics were performed using Statview 3.0 and Prism.

Pavlovian olfactory learning and memory. Drosophila were raised at $22^{\circ} \mathrm{C}$ and placed at $25^{\circ} \mathrm{C}$ overnight before behavioral experiments. Adult Drosophila 3- to 5-d-old were trained and tested with the classical conditioning procedure of Tully and Quinn (1985). Flies were treated with either drug or vehicle contained in the food for $1 \mathrm{~d}$ before testing. Approximately 100 flies were trapped inside a training chamber, covered with an electrifiable copper grid. Flies were allowed $90 \mathrm{~s}$ to acclimate and then were exposed sequentially to two odors, 3-octanol (OCT) and 4-methylcyclohexanol (MCH), carried through the chamber in a current of air $(750 \mathrm{ml} / \mathrm{min}$; relative concentrations of OCT and MCH were adjusted so that naive flies distributed themselves 50:50 in the T-maze). Flies first were exposed for $60 \mathrm{~s}$ to the conditioned stimulus $\left(\mathrm{CS}^{+}\right.$; either OCT or $\mathrm{MCH})$, during which time they received the unconditioned stimulus (US; twelve $1.25 \mathrm{~s}$ pulses of $60 \mathrm{~V}$ DC electric shock at $5 \mathrm{~s}$ interpulse intervals). After the $\mathrm{CS}^{+}$presentation, the chamber was flushed with fresh air for $45 \mathrm{~s}$. Then flies were exposed for $60 \mathrm{~s}$ to a second, control stimulus ( $\mathrm{CS}^{-}$; either $\mathrm{MCH}$ or OCT depending on the odor the flies were shocked to in the first step), which was not paired with electric shock. After the $\mathrm{CS}^{-}$presentation, the chamber was again flushed with fresh air for $45 \mathrm{~s}$. To test for conditioned odor avoidance after classical conditioning, flies were tapped gently from the training chamber into an elevatorlike compartment that transports them to the choice point of the T-maze. Ninety seconds later, the flies were exposed to two converging current of air (one carrying OCT, the other $\mathrm{MCH}$ ) from opposite arms of the T-maze. Flies were allowed to choose between the $\mathrm{CS}^{+}$and $\mathrm{CS}^{-}$for $120 \mathrm{~s}$, at which time they were trapped inside their respective arms of the T-maze (by sliding the elevator out of register), anesthetized, and counted.

Two groups of flies were trained and tested in one complete experiment. The $\mathrm{CS}^{+}$was OCT and the $\mathrm{CS}^{-}$was $\mathrm{MCH}$ for one group; the $\mathrm{CS}^{+}$ was $\mathrm{MCH}$ and the $\mathrm{CS}^{-}$was OCT for the second group. The performance index (PI) was calculated as the average of the fraction of the population 
avoiding the shock-associated odor minus the fraction avoiding the control odor for each group of flies trained in one experiment. In other words, the PI enumerates the distribution of flies in the T-maze as a normalized "percent correctly avoiding the shock-paired odor" and ranges from 0 for a 50:50 distribution to 100 for a 100:0 distribution.

Data from an experiment were subjected to a one-way ANOVA (JMP from SAS), followed by planned pairwise comparisons as indicated in text and figure legend. An $\alpha=0.05$ was corrected for multiple comparisons using Bonferroni. Post-test analysis was performed with Tukey test. All graphs depict mean \pm SEM.

Olfactory memory task-relevant sensorimotor responses. Olfactory acuity and shock reactivity were assessed as in Tully and Quinn (1985) and Yin et al. (1995). Briefly, odor avoidance at the concentrations used for the conditioning experiments was quantified in mutant and control flies. Naive flies were placed in the T-maze and given a choice between an odor $(\mathrm{OCT}$ or $\mathrm{MCH})$ and air. The odor is naturally aversive, and flies usually avoided the T-maze arm containing the odor (OCT or $\mathrm{MCH}$ ) by running into the opposite arm (air). After the flies distributed themselves for 2 min, they were trapped, anesthetized, and counted. For shock reactivity, flies were given a choice between an electrified grid in one T-maze arm and an unconnected grid in the other. After the flies distributed themselves for $2 \mathrm{~min}$, they were trapped, anesthetized, and counted.

Drosophila $c A M P$ quantification. The Direct cAMP ELISA kit (ENZO Life Sciences) was used to measure cAMP content. Male flies were collected between 0 and $24 \mathrm{~h}$ after eclosion and placed on food containing either $100 \mu \mathrm{M}$ rolipram or ethanol vehicle for $1 \mathrm{~d}$, after which they were immediately snap-frozen on dry ice. The frozen heads were subsequently harvested to generate samples each containing 50 heads. This tissue was homogenized on wet ice in $500 \mu \mathrm{l}$ of $0.1 \mathrm{M} \mathrm{HCl}$, and the lysate was placed in a $4^{\circ} \mathrm{C}$ centrifuge for $10 \mathrm{~min}$ at $1000 \mathrm{rpm}$. Supernatant was then collected, and cAMP levels were measured using the ELISA-based assay kit as per the manufacturer's instructions. The cAMP concentrations obtained were then normalized to the protein content in the original lysate as determined by the Pierce BCA Protein Assay Kit (Thermo Scientific). Three biological replicates for each genotype and treatment were used to determine cAMP levels. The data were analyzed using SPSS (Version 22). A one-way ANOVA revealed a significant interaction between groups; thus, post hoc one-tailed $t$ tests were used to test our a priori hypotheses.

Mouse husbandry. All animal studies were conducted in accordance with protocols approved by the Institutional Animal Care and Use Committee at the Drexel University College of Medicine and Albert Einstein College of Medicine. Mice that are homozygous (female) or hemizygous (male) for a targeted mutation in the Fmrl gene on the X chromosome and backcrossed for 11 generations onto the FVB background were purchased from the The Jackson Laboratory and bred in-house (Fmr1 KO mice) as was the appropriate genetic control strain, the same genetic background also purchased from Jackson (Choi et al., 2011), both mutant and wild-type (WT) strains had the mutation causing blindness with aging that was initially in the background crossed out (corrected), and these mice were purchased from The Jackson Laboratory and bred inhouse (Fmrl KO mice) as were the appropriate control strains. Genotype verification was obtained using PCR on DNA extracted from tail tissue. All mice were subjected to a $12 \mathrm{~h}$ light: $12 \mathrm{~h}$ dark cycle. Food and water were provided ad libitum, and only male mice were used.

Electrophysiology of brain slices. Electrophysiology was performed as in Choi et al. (2011). Mice were deeply anesthetized with isoflurane and decapitated. Brains were collected in ice-cold dissection buffer (in mM as follows: 215 sucrose, $26 \mathrm{NaHCO}_{3}, 1.6 \mathrm{NaH}_{2} \mathrm{PO}_{4}, 1 \mathrm{CaCl}_{2}, 2.5 \mathrm{KCl}, 4$ $\mathrm{MgSO}_{4}, 4 \mathrm{MgCl}_{2}, 20$ glucose), and the hippocampi were dissected. Transverse sections of the hippocampi (400 $\mu \mathrm{m}$ thickness) were prepared in ice-cold aCSF (in mM as follows: $124 \mathrm{NaCl}, 25 \mathrm{NaHCO}_{3}, 1.25 \mathrm{NaH}_{2} \mathrm{PO}_{4}$, $2.5 \mathrm{CaCl}_{2}, 2.5 \mathrm{KCl}, 1.3 \mathrm{MgCl}_{2}, 10$ glucose) using a vibrating slicer (Vibratome $3000 \mathrm{EP}$, Vibratome). Slices were allowed to recover at $33^{\circ} \mathrm{C}$ for $1 \mathrm{~h}$ before transecting the CA3 region and placing them in a submersionstyle recording chamber, where they were perfused for at least $1 \mathrm{~h}\left(32^{\circ} \mathrm{C}\right.$, $2-2.5 \mathrm{ml} / \mathrm{min}$ ) before recording. Dissection and recording buffers were saturated with a $95 \% \mathrm{O}_{2} / 5 \% \mathrm{CO}_{2}$ mixture, $\mathrm{pH}$ 7.4. Extracellular field EPSPs (fEPSPs) were recorded in the stratum radiatum of area CA1 using extracellular recording electrodes filled with aCSF (resistances: 1-2
MOhm). Synaptic responses were evoked by stimulating the Schaffer collateral axons with a $200 \mu$ s pulse using a bipolar stainless steel electrode (Rhodes Medical Instruments). Slices were stimulated every $30 \mathrm{~s}$ $(0.033 \mathrm{~Hz})$ for a minimum of $30 \mathrm{~min}$ to verify stability of response. Basal synaptic transmission was measured by stimulating the slices at $8-10$ different stimulus intensities ranging from 5 to $50 \mu \mathrm{A}$. Paired-pulse facilitation (PPF) was determined at interstimulus intervals of 15, 30, 50, and $100 \mathrm{~ms}$. Baseline responses were evoked by stimulating the slices at $0.033 \mathrm{~Hz}$ using $50 \%-60 \%$ of maximal stimulating intensity, and the data were averaged every minute for a minimum of $30 \mathrm{~min}$. Slices were not further used if their responses drifted beyond $5 \%$ of the average baseline response. LTD was induced chemically by applying $100 \mu \mathrm{M}(\mathrm{R}, \mathrm{S})$ dihydroxyphenylglycine (DHPG) for $10 \mathrm{~min}$. Extracellular recordings were performed with a Multi-Clamp 700A amplifier (Molecular Devices). Analysis of data was performed blind to the genotype and experimental group. Results were obtained using at least two different litters of mice for all experimental groups. All experiments were interleaved as appropriate. Basal synaptic transmission and PPF results are reported as mean \pm SD. LTD results are reported as mean \pm SEM. Significant differences between groups were determined using a Student's $t$ test and ANOVA analysis. Significance was similar for all data analyzed by both the Student's $t$ test and ANOVA; therefore, only the ANOVA $p$ values are shown.

Drug administration in mice. R,S-DHPG, rolipram, and LY341495 were purchased from Tocris Bioscience. DHPG was solubilized as a 50 mM stock in water; rolipram was prepared as a $100 \mathrm{~mm}$ stock in DMSO. All solubilized drugs were aliquoted and frozen at $-20^{\circ} \mathrm{C}$. Fresh stocks were prepared weekly for DHPG and biweekly for the other two drugs.

Eight- to 10-week-old male Fmrl KO mice and age-matched male control mice were administered $0.9 \%$ saline containing $0.03 \mathrm{mg} / \mathrm{kg}$ rolipram or vehicle alone ( $0.03 \%$ DMSO) via subcutaneous injections once daily for 8 weeks. This dose was previously reported to achieve concentrations between $0.06 \mu \mathrm{M}$ and $0.2 \mu \mathrm{M}$ in the brain (Barad et al., 1998; Gong et al., 2004). The mice were given a $3-5$ week drug hiatus before testing (Gong et al., 2004). Mice were weighed weekly to help monitor general well-being.

\section{Results}

\section{PDE-4 inhibition rescues memory in the Drosophila fragile} $\mathrm{X}$ model

The Drosophila model of fragile $\mathrm{X}$ is based on loss of function of $d f m r 1$, the Drosophila ortholog of FMR1. For our studies, we use a $d f m r 1$ deletion line carrying a genomic transgene with a frameshift mutation engineered in the $d f m r l$ coding region that is driven by the endogenous promoter, referred to as the FS line. The control line for these studies contains the same deletion of the $d f m r l$ gene but also carries a WT transgene for $d f m r l$ that is driven by the endogenous promoter and is referred to as the WT line (Dockendorff et al., 2002; McBride et al., 2005).

In Drosophila, cognitive ability can be assessed using the conditioned courtship-associative memory paradigm. A male fly will display a semistereotyped set of courtship behaviors when paired with a female. These behaviors can be scored, and the percentage of time spent engaged in these courtship behaviors during a testing period is referred to as a CI (Siegel and Hall 1979). If a male is paired with a previously mated female over the course of $1 \mathrm{~h}$, his courtship will decrease during the training period due to the female's aversive cues and rejection of his advances. This decrease in courtship during the training period is referred to as learning during training (LDT) (Joiner and Griffith, 1997; Kane et al., 1997; McBride et al., 2010). Additionally, the male will continue to have lower courtship activity when subsequently paired with a virgin female, compared with males that are not paired with a previously mated female. This lower courtship activity is indicative of a memory of the training. An alternative version of this paradigm pairs the trained male with a novel previously mated 
A

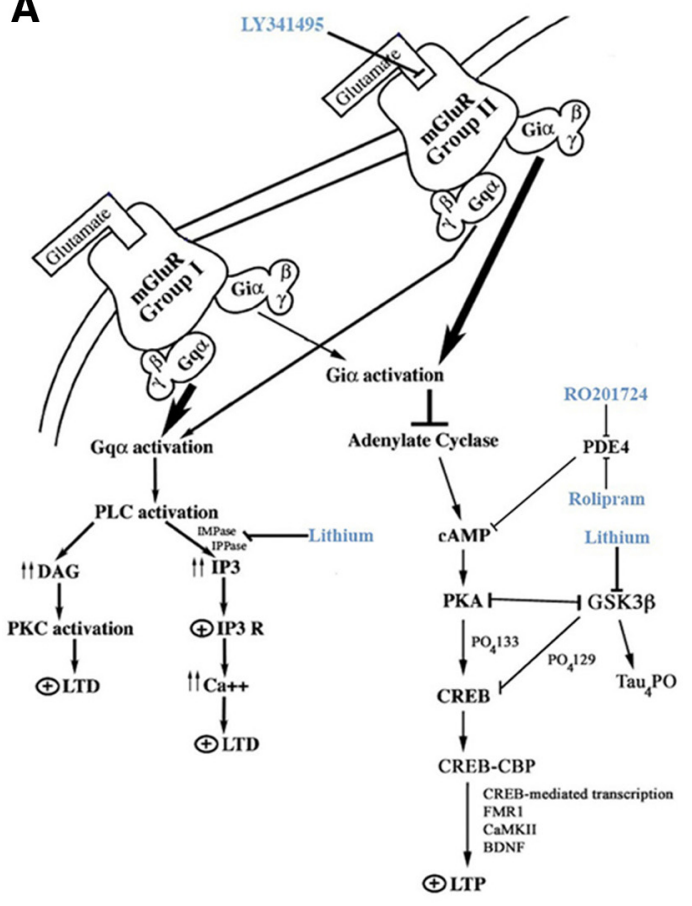

D



F

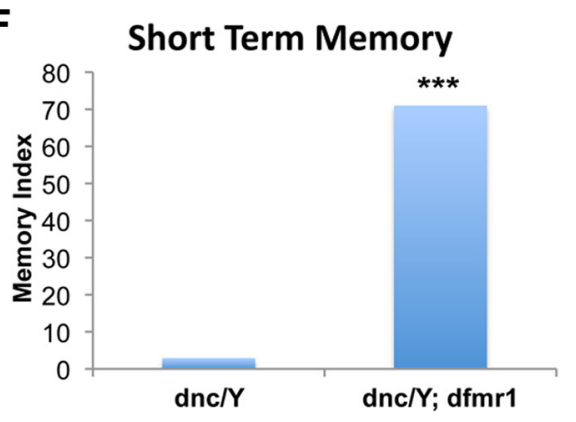

B



C

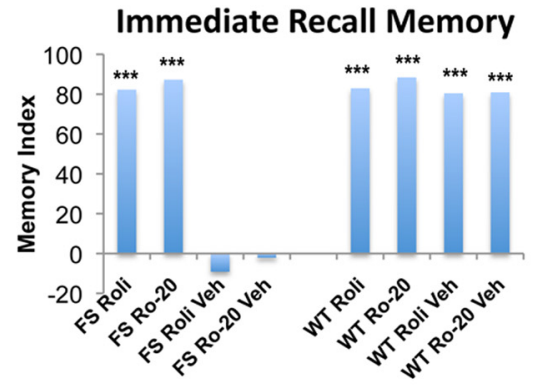

E

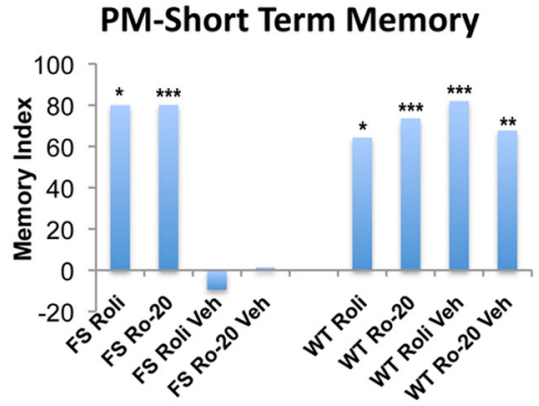

G PM-Short Term Memory

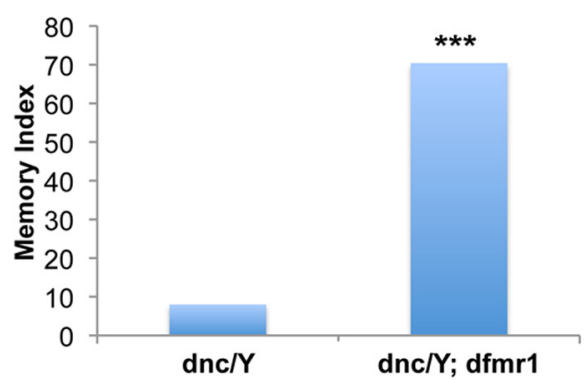

Figure 1. Rescue of memory in fragile X flies treated with PDE-4 inhibitors. $A$, The signal transduction pathway demonstrating the potential role for PDE- 4 inhibitors in the treatment of fragile $X$. The mGluR Group I and mGluR Group II signal transduction pathways are shown. Previously, it has been demonstrated that antagonizing or dampening the signaling of either of the mGluR pathways can rescue multiple phenotypes in the fly and mouse models of fragile X, including memory, audiogenic seizure, and enhanced mGluR-LTD (McBride et al., 2005; Yan et al., 2005; Dölen et al., 2007; Choi et al., 2010, 2011). Additionally, lithium has demonstrated efficacy in rescuing cognitive abilities, audiogenic seizure, and enhanced mGluR-LTD in fly and mouse models as well as in human patients (McBride et al., 2005; Berry-Kravis et al., 2008; Min et al., 2009; Choi et al., 2010, 2011; Yuskaitis et al., 2010b; Liu et al., 2011). As shown in the figure, PDE-4 also intersects in this signaling cascade. B, cAMP levels were lower in dfmr 1 mutant versus control heads obtained from vehicle-treated flies. This deficit in cAMP levels was rescued by treatment with rolipram. ${ }^{*} p<0.05$. C, Immediate-recall memory (0 min after training) was measured in WT and FS flies that were administered vehicle control food, rolipram (Roli), or Ro-20-1724 (Ro-20) drug treatments. WT flies kept on vehicle (Veh), rolipram, or Ro-20-1724 demonstrate immediate-recall memory. FS flies kept on vehicle fail to demonstrate memory. In contrast, FS flies treated with rolipram or Ro-20-1724 display immediate-recall memory at 0 min after training. Data are expressed as a Memory Index. ${ }^{*} p<0.05 .{ }^{* *} p<0.01 .{ }^{* * *} p<0.001$. The $N$ values were at least 34 flies for each test group. $\boldsymbol{D}$, Short-term memory (60 min after training) was measured in WT and FS flies that were treated as in C. WT flies kept on vehicle, rolipram, or Ro20 -1724 demonstrate short-term memory. FS flies kept on vehicle fail to demonstrate short-term memory, whereas those treated with rolipram or Ro-20-1724 display short-term memory at 60 min after training. (Figure legend continues.) 
female target after training (Siegel and Hall, 1979; Kamyshev et al., 1999; McBride et al., 2005). The comparison is then between the CI during the initial 10 min period of training and the CI during the testing period (Kamyshev et al., 1999; McBride et al., 2005). Again, a reduction in CI during the testing period is indicative of memory. The CIs are used to calculate a memory index, which is used in the graphs where a higher score is indicative of memory and scores closer to 0 or negative values are indicative of no memory of the training. Males can be tested immediately after training to assess immediate-recall memory or $60 \mathrm{~min}$ after training to assess short-term memory.

FS flies have been demonstrated to have impairments in immediate recall, short-term memory, and long-term memory in the conditioned courtship paradigm (McBride et al., 2005; Banerjee et al., 2010; Choi et al., 2010). Previous studies have identified a defect in cAMP levels that is conserved from the fly and mouse FXS models to cells derived from FXS patients (BerryKravis and Huttenlocher 1992; Berry-Kravis et al., 1995; BerryKravis and Ciurlionis 1998; Kelley et al., 2007). We chose to inhibit the Drosophila PDE-4, which hydrolyzes cAMP, with the pharmacologic inhibitors rolipram and Ro-20-1724. We hypothesized that PDE-4 inhibition may rescue memory by elevating cAMP levels because cAMP levels may be suppressed by the overactive mGluR signaling in the fragile $\mathrm{X}$ fly model (Fig. $1 \mathrm{~A}$ ) (McBride et al., 2005; Kanellopoulos et al., 2012). Rolipram has been demonstrated to have efficacy in WT Drosophila and heterozygous FS mutant Drosophila at doses higher than those used in earlier studies in elevating cAMP levels (Henkel-Tigges and Davis, 1990; Hou et al., 2004); Kanellopoulos et al., 2012). Rolipram has also been demonstrated to increase CREBmediated gene transcription in Drosophila (Hou et al., 2004) and increase cAMP levels after feeding (Kanellopoulos et al., 2012). Thus, it may be able to partially circumvent the mGluR-mediated inhibition of cAMP signaling incurred in fragile $\mathrm{X}$ cells. In line with this thinking and consistent with previous studies, we found that cAMP levels were reduced in the heads of $d f m r 1$ mutant flies compared with genetic controls and that this deficit was rescued by treatment with rolipram (Fig. 1B).

To test the hypothesis that PDE- 4 inhibition may rescue cognitive impairments in fragile X flies, FS and WT flies were treated with rolipram, Ro-20-1724, or the appropriate vehicle for $9 \mathrm{~d}$ (starting on the first day of eclosion) and then tested for immediate-recall ( 0 min memory) and short-term memory (60 min memory) as well as LDT and short-term memory in an alternative courtship-based memory paradigm that uses a previously mated target female. FS flies demonstrated rescued immediate-recall memory and short-term courtship memory af-

\footnotetext{
(Figure legend continued.) $\boldsymbol{E}$, Short-term (60 min) memory, tested with premated females (PM) as targets, was measured in WT and FS flies that were treated as in C. WT flies on all three treatments demonstrate a significant decrease in courtship toward a premated female target at 60 min after training (short-term memory) compared with the initial courtship, demonstrating memory in this alternate memory-testing paradigm. FS flies kept on vehicle fail to demonstrate memory at $60 \mathrm{~min}$ after training. In contrast, FS flies treated with rolipram or Ro20-1724 display short-term memory at $60 \mathrm{~min}$ after training. $\boldsymbol{F}$, Short-term memory ( $60 \mathrm{~min}$ ) was measured in fragile $X$ flies containing the dunce mutation, resulting in loss of function of the PDE-4 protein. Fragile $X$ flies harboring the dunce mutation display short-term memory at 60 min after training, whereas flies containing the dunce mutation alone lack detectable memory. G, Shortterm memory $(60 \mathrm{~min}$ ) using the alternative memory paradigm was measured in fragile $X$ flies containing the dunce mutation. Fragile X flies harboring the dunce mutation display short-term memory at 60 min after training in the alternative paradigm, whereas flies containing the dunce mutation alone lack detectable memory.
}

ter treatment with both PDE-4 inhibitors. In contrast, FS flies continued to have impaired immediate-recall memory and short-term memory when treated with the vehicle controls for rolipram and Ro-20-1724 (Fig. 1C,D). WT flies displayed intact immediate-recall memory or short-term memory when treated with PDE-4 inhibitors or vehicle (Fig. 1C,D). FS and WT flies displayed intact LDT regardless of treatment (data not shown). LDT in young adult FS flies has been previously demonstrated to be intact, and our results demonstrate that PDE-4 inhibition does not impair LTD (McBride et al., 2005; Choi et al., 2010). Treatment with either the PDE-4 inhibitor rolipram or Ro-20-1724 rescued short-term memory in the alternative courtship memory paradigm in FS flies, whereas vehicle treatment did not (Fig. 1E). WT flies displayed intact short-term memory on vehicle or PDE-4 inhibitor treatments (Fig. 1E).

Another paradigm that has been used extensively in Drosophila to test cognition is based on classical olfactory conditioning that couples odors to shock treatment (Tully and Quinn 1985; Skoulakis and Grammenoudi 2006; Bolduc and Tully 2009). Indeed, the first memory mutants identified in Drosophila were dunce (PDE-4) (Dudai et al., 1976) and rutabaga (adenylate cyclase) (Duerr and Quinn 1982). Conditioned courtship and olfactory conditioning (Pavlovian conditioning) have allowed for a genetic dissection of each stage of memory formation from learning to long-term memory in Drosophila.

In previous studies, Bolduc et al. (2008) demonstrated that FS flies have impairments in the Pavlovian conditioning paradigm. We therefore tested whether rolipram treatment could also rescue the olfactory-based memory phenotypes to gain additional evidence of the efficacy of PDE-4 inhibitor treatment. We found that FS flies that were treated acutely for $12 \mathrm{~h}$ with rolipram at 50 $\mu \mathrm{M}$ displayed rescue of immediate-recall memory (referred to as learning), whereas there was no effect in the vehicle treatment (Fig. 2A). WT rescue flies did not show any change in performance with rolipram. This likely reflects the acute role of FMRP influencing cAMP signaling during learning (immediate-recall memory). Additionally, rolipram treatment did not appear to alter sensory or motor function in the FS flies (Fig. 2B,C).

We next wanted to genetically validate the specificity of the PDE-4 inhibitor treatments by crossing in the dunce mutation into the $d f m r 1$ mutant background. The dunce mutation is a lossof-function mutation of the PDE-4 gene, resulting in abnormally high cAMP levels and memory impairment (Byers et al., 1981; Davis and Kiger 1981). We found that $d f m r 1$ mutant flies carrying the dunce mutation demonstrated rescued short-term memory in the standard and alternative memory paradigms (Fig. $1 F, G$ ), whereas no memory was detected in the dunce mutant flies (Fig. $1 F, G)$. These results validate PDE- 4 as a potential therapeutic drug target for the amelioration of cognitive impairment displayed in fragile $\mathrm{X}$.

Importantly, the rescue of memory (courtship) and learning (olfactory) appears to be independent of developmental malformation observed in the FS fly model. The MBs are a structure in the insect brain that was first speculated to be involved in memory by having an analogous structure to the human hippocampus and is currently often regarded as the analogous structure in the fly (Dujardin, 1850; O'Kane 2011). The MBs were demonstrated to be required for short-term and long-term memory in the conditioned courtship paradigm (McBride et al., 1999) and the olfactory-based paradigm (Zars et al., 2000; Pascual and Préat 2001). Fragile $X$ model flies exhibit a phenotype of aberrant midline crossing of the $\beta$ lobes of the mushroom bodies, which is corrected by treatment with mGluR antagonists or lithium 
A

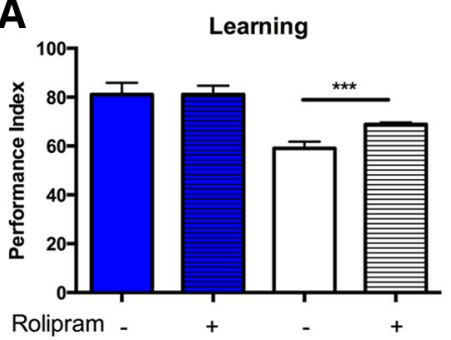

B



C

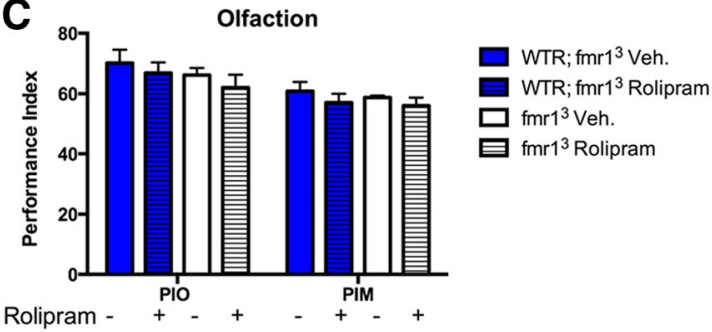

Figure 2. Rolipram rescues the olfactory-based learning defect observed in dfmr 1 mutants. A, Immediate olfactory conditioning memory, referred to as learning, was significantly improved in FS mutant after being administered an acute dose of $50 \mu \mathrm{m}$ rolipram. The levels of significance are indicated as follows. ${ }^{* * *} p<0.001$. No effect was observed in WT controls. $N=6 \mathrm{Pls}$ per group. $B$, One- to 3-d-old FS mutants as well as their WT rescue controls present with a normal shock avoidance with vehicle and rolipram treatment. $N=6$ Pls per genotype. $C$, One- to 3-d-old FS mutant and WT rescue controls present with normal avoidance to the odors $(\mathrm{OCT}$ or $\mathrm{MCH})$ used in the classical conditioning experiments. $N=6$ Pls per genotype.

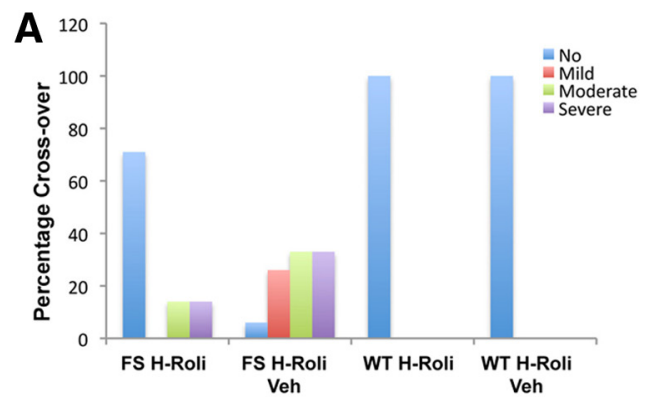

B



C

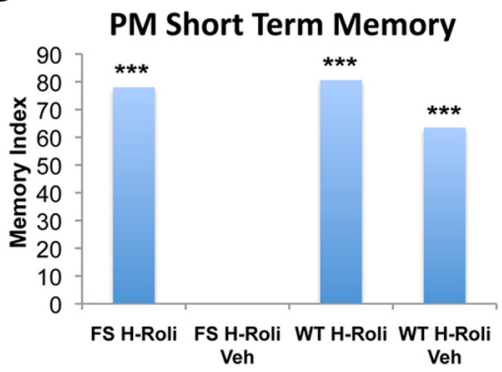

Figure 3. MB morphology is rescued with a high dose of rolipram. $A, M B$ morphology was examined in WT and FS flies grown in food containing vehicle or a high dose of rolipram. The morphology of the MBs was performed as described previously (Michel et al., 2004; McBride et al., 2005). The MBs in WT fly brains were normal after vehicle or high-dose rolipram treatment. More than 90\% of the MBs in FS fly raised on vehicle control food displayed a range of crossover defects; however, significantly fewer MBs displayed crossover defects when the FS flies were raised on food containing a high dose of rolipram. B, Short-term memory (60 min) was measured in WT and FS flies that were administered vehicle control food or high-dose rolipram treatments. WT flies kept on a high dose of rolipram or vehicle demonstrate short-term memory. FS flies kept on vehicle fail to demonstrate short-term memory. In contrast, FS flies treated with the high-dose rolipram display short-term memory at 60 min after training. C, Short-term ( $60 \mathrm{~min}$ ) memory was measured in WT and FS flies that were treated as described in $\boldsymbol{B}$ and tested in an alternative short-term memory paradigm where a previously mated female was used as the target during the testing period. WT flies kept on vehicle or high-dose rolipram demonstrate short-term memory. FS flies kept on vehicle fail to demonstrate short-term memory. In contrast, FS flies treated with a high dose of rolipram demonstrate short-term memory. ${ }^{*} p<0.05,{ }^{* *} p<0.01$, ${ }^{* * *} p<0.001$. The $N$ values were at least 34 flies for each test group.

(McBride et al., 2005). The PDE-4 inhibitor, rolipram, at the treatment dose that rescued memory $(50 \mu \mathrm{M})$ did not rescue the phenotype of aberrant midline crossing by the $\beta$ lobes of the mushroom bodies in the brains of FS flies (data not shown). However, a higher dose of rolipram $(500 \mu \mathrm{M})$ did rescue the phenotype of aberrant midline crossing by the $\beta$ lobes of the MBs in the brains of FS flies, whereas vehicle treatment had no effect (Fig. 3A). This result left us with two possible explanations of how the higher dose that rescues the midline-crossing defect would affect memory: it could make it worse or it could continue to rescue memory. We then reexamined the memory of FS flies with this higher dose of rolipram and found that even this high dose of rolipram continued to demonstrate efficacy in the rescue of short-term memory in both the standard and alternative shortterm memory paradigms, whereas vehicle treatment did not (Fig. $3 B, C)$.

Chronic adult onset PDE-4 inhibitor treatment abrogates the enhanced mGluR LTD in fragile X mice

We next tested whether the PDE-4 inhibitor rolipram could be effective in Fmrl KO mice. Because memory impairments have been difficult to replicate in this model, we chose to focus on a very reproducible electrophysiological phenotype. The most robust electrophysiological phenotype displayed by the fragile $\mathrm{X}$ mouse model is exaggerated mGluR-dependent LTD in the CA1 region of the hippocampus (Huber et al., 2002). We therefore decided to investigate the effects of PDE-4 inhibition on this form of LTD in the mouse model. We first tested the efficacy of chronic treatment in adulthood. In this study, mGluR-dependent LTD was induced by treating hippocampal slices with $100 \mu \mathrm{M}$ DHPG for $10 \mathrm{~min}$, which has been shown to stimulate mGluR-LTD in WT mice (Huber et al., 2000, 2001; Choi et al., 2011).

Rolipram was chosen as the drug treatment to inhibit PDE-4 in vivo because of the high degree of selectivity and established dosing regimens in rats and mice (Barad et al., 1998; Gong et al., 2004). Rolipram or DMSO vehicle treatment was given to littermate control (WT) and Fmr1 KO mice for 8 weeks beginning at $8-10$ weeks of age. At the cessation of treatment, the mice were given a treatment-free hiatus for 3-5 weeks before being tested for DHPG-induced LTD. This was done to establish that longlasting changes had occurred in the mice and to ensure that no rolipram or vehicles was remaining in the system during the electrophysiology experiments for the chronic treatments (Gong et al., 2004; Choi et al., 2011). In a similar experimental design, rolipram treatments at this dose chronically for 3 weeks have been demonstrated to have effects several months after treatment cessation with regard to behavior, electrophysiology, and biochemistry where increased phosphorylation of CREB at s133 continued to be increased after treatment (Gong et al., 2004). In WT mice, an 8 week treatment with DMSO vehicle had no effect on DHPG-induced mGluR-LTD, with depression of fEPSP slope values to $82.7 \pm 2.8 \%$ and $83.4 \pm 1.4 \%$ at 60 and $80 \mathrm{~min}$, respectively, after induction (Figs. $4 A$ and $5 D, E$ ). In contrast, WT mice that were chronically treated with rolipram demonstrated en- 


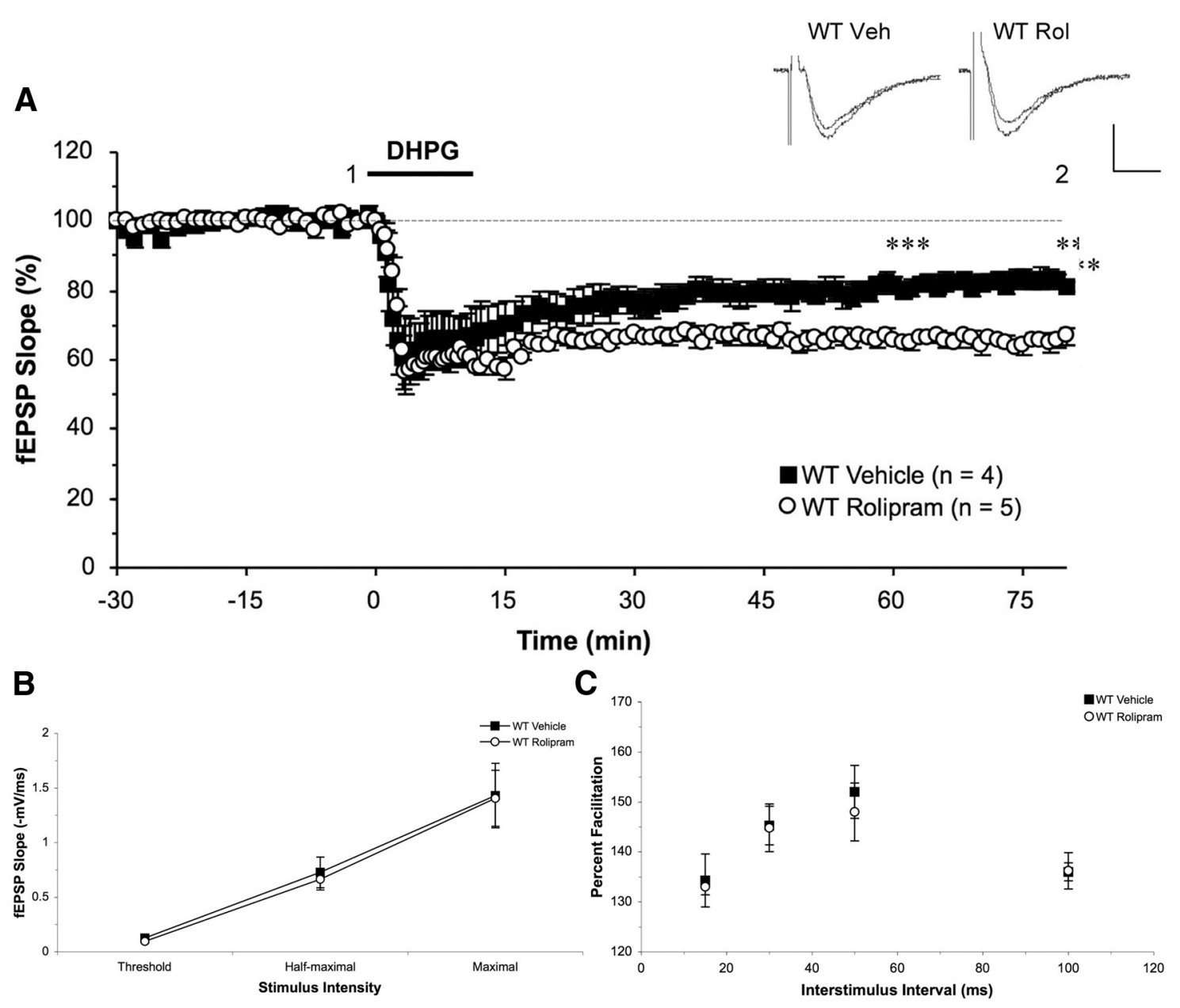

Figure 4. Long-term treatment of WT mice with rolipram enhances mGluR-LTD. A, Eight- to 10-week-old WT mice were administered daily injections of rolipram for 8 weeks followed by a hiatus of 3-5 weeks. mGluR-LTD was induced by brief bath application of the mGluR agonist DHPG (100 $\mu \mathrm{m}, 10 \mathrm{~min})$. Plotted are average fEPSP slopes ( \pm SEM) as a percentage of average preinduction baseline values. Representative traces of field potentials are from times indicated by the numbers on the graph (1 and 2). Calibration: $1.5 \mathrm{mV}, 5 \mathrm{~ms}$. mGluR-LTD was significantly enhanced in rolipram-treated WT mice ( $n=5$ slices, 5 mice, open circles) compared with interleaved age-matched vehicle-treated WT mice $(n=4$ slices, 4 mice, filled squares) at 60 min (WT vehicle: $82.7 \pm$ 2.8\%; WT rolipram: $67.4 \pm 1.5 \% ;{ }^{* * *} p=0.0001$ ) and at $80 \mathrm{~min}$ (WT vehicle: $83.4 \pm 1.4 \%$;WT rolipram: $65.6 \pm 2.4 \% ;{ }^{* * *} p=0.0001$ ) after induction. $\boldsymbol{B}$, Basal synaptic transmission is not affected by chronic rolipram treatment in WT mice. Mean evoked fEPSP slopes ( \pm SD) are plotted at three different stimulus intensities. Synaptic responses at threshold, half-maximal, and maximal stimulus intensities were not significantly different between rolipram-treated WT mice ( $n=5$ slices, 5 mice, open circles) and interleaved age-matched vehicle-treated WT mice $(n=4$ slices, 4 mice, filled squares). C, PPF in WT mice after chronic rolipram treatment ( $n=5$ slices, 5 mice, open circles) and interleaved age-matched vehicle-treated WT mice ( $n=4$ slices, $4 \mathrm{mice}$, filled squares) was not different. Synaptic responses to paired stimulation were evoked at interstimulus intervals ranging from 15 to $100 \mathrm{~ms}$. Plotted are the mean percentage facilitation ( \pm SD), as determined by calculating the ratio of the second fEPSP slope to the first fEPSP slope.

hanced LTD of synaptic transmission at 60 and $80 \min (67.4 \pm$ $1.5 \%$ and $65.6 \pm 2.4 \%$, respectively) (Figs. $4 A$ and $5 D, E$ ). There was no difference in basal synaptic transmission between WT mice treated with rolipram or DMSO vehicle (Fig. $4 B$ ). Also, there was no difference in PPF between WT mice treated with rolipram or DMSO vehicle, suggesting that chronic rolipram treatment did not have an effect on presynaptic release mechanisms in the CA1 region of the hippocampus (Fig. 4C).

In Fmrl KO mice, an 8 week treatment with DMSO vehicle had no effect on DHPG-induced mGluR-LTD, with LTD of $69.3 \pm 1.4 \%$ and $71.1 \pm 2.1 \%$ at 60 and $80 \mathrm{~min}$ after induction, which remained significantly enhanced compared with LTD in interleaved, age-matched, DMSO vehicle-treated WT mice at 60 and $80 \mathrm{~min}(82.7 \pm 2.8 \%$ and $83.4 \pm 1.4 \%$; Fig. $5 A, D, E)$. In contrast, Fmr1 KO mice that were chronically treated with rolipram demonstrated abrogation of the enhanced mGluR-LTD endophenotype at 60 and $80 \mathrm{~min}$ after induction $(87.6 \pm 1.9 \%$ and $87.6 \pm 1.9 \%$; Fig. $5 A, D, E)$. Basal synaptic transmission and PPF were not significantly different between DMSO vehicle-treated and rolipram-treated Fmrl KO mice (Fig. 5B,C).

Acute pharmacologic PDE-4 inhibition restores mGluRdependent LTD to normal levels in Fmr1 KO mice

mGluR-LTD was examined in hippocampal slices from untreated WT and Fmr $1 \mathrm{KO}$ mice (at 20-23 weeks of age) after acute bath application of rolipram at a concentration that is within the range observed in the brain of mice during chronic treatment (Barad et al., 1998; Gong et al., 2004). Acute experiments differ from chronic treatment in that a drug effect is examined on the unadulterated state of the synapse. Signaling at the synapse in WT mice is presumed to be set up to maintain a homeostatic balance leading to optimal LTD in response to appropriate synaptic stimulation, an inverted U-model of signaling with regard cAMP (Sato et al., 2004). In the inverted U-model of homeostatic balance with regard to cAMP signaling, the optimal level of cAMP will allow for proper signaling and memory formation, whereas 


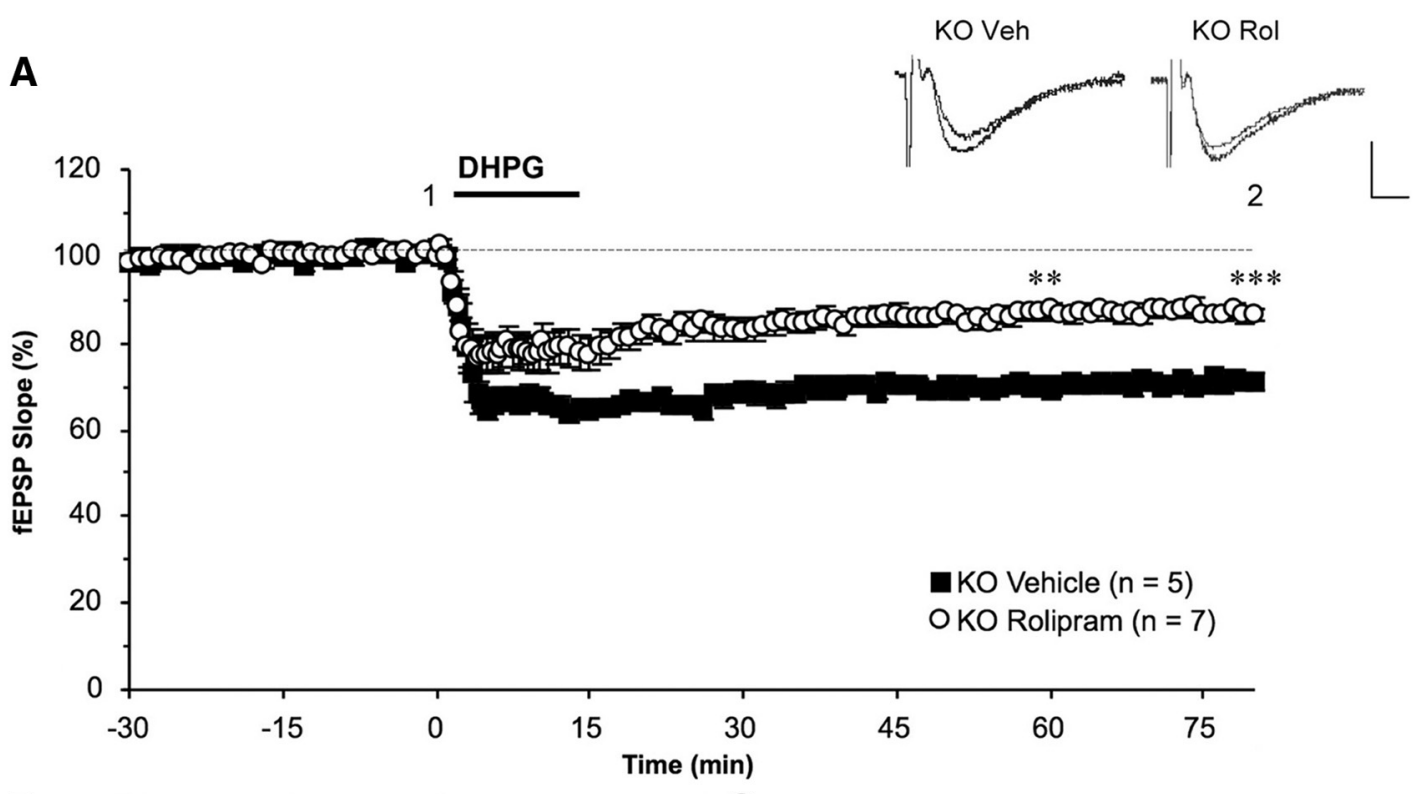

B

C
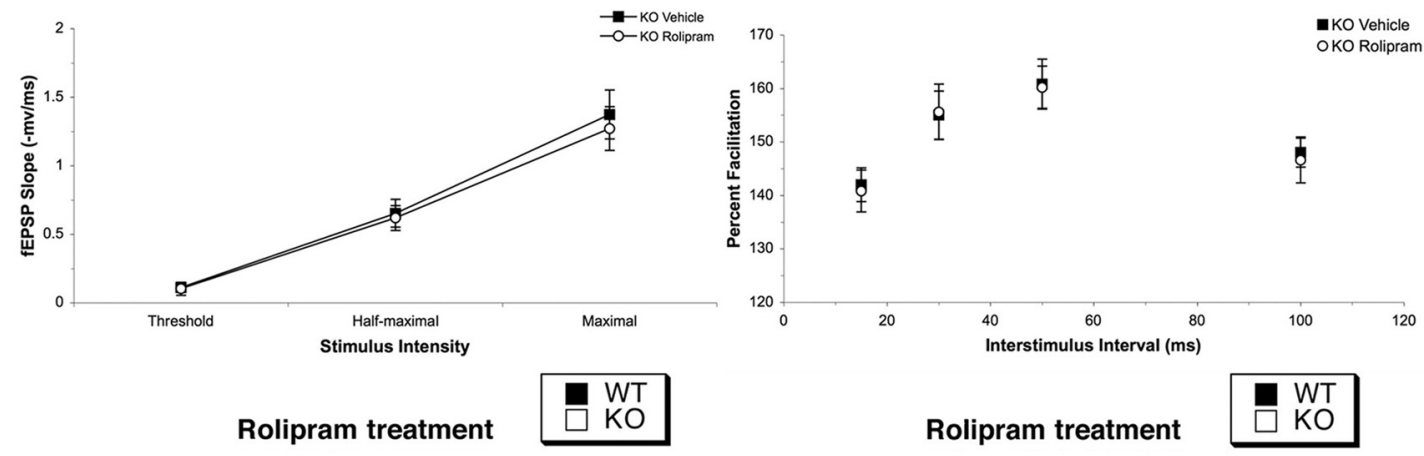

D

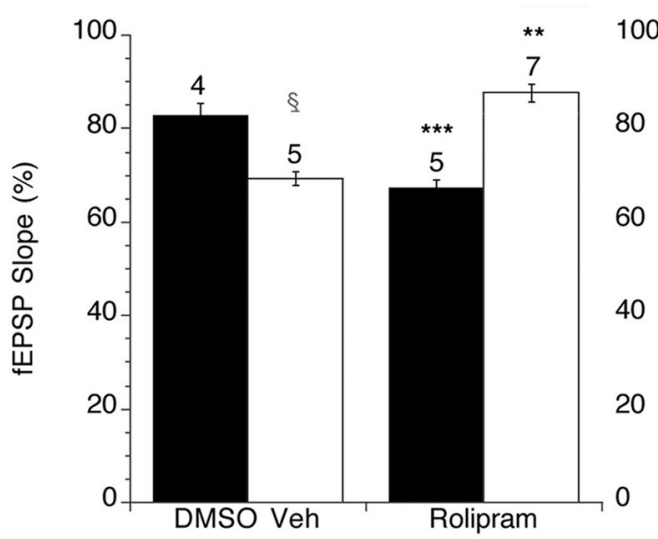

60 minutes

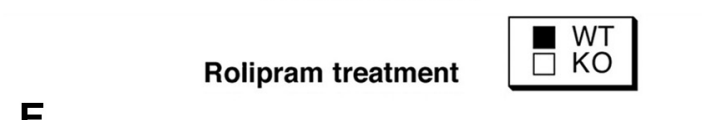

E

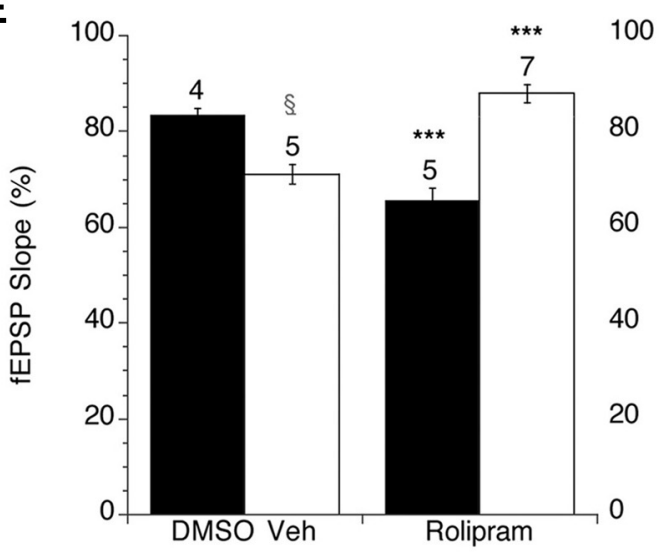

80 minutes

Figure 5. Long-term treatment of fragile X mice with rolipram. $A$, Eight- to 10 -week-old $F m r 1 K 0$ mice were administered daily injections of rolipram for 8 weeks followed by a hiatus of 3-5 weeks. LTD was induced, measured, and plotted as described in Figure 2 . mGluR-LTD was significantly enhanced in vehicle-treated $F m r 1 \mathrm{KO}$ mice $(n=5$ slices, 5 mice, filled squares $)$ compared with interleaved age-matched vehicle-treated WT mice (Fig. $2 ; n=4$ slices, 4 mice, filled squares) at $60 \mathrm{~min}$ (WT vehicle: $82.7 \pm 2.8 \%$; Fmr $1 \mathrm{KO}$ vehicle: $69.3 \pm 1.4 \%$; Fig. $3 A, D, p=0.0001$ ) and at 80 $\min$ (WT vehicle: $83.4 \pm 1.4 \% ; F m r 1$ KO vehicle: $71.1 \pm 2.1 \%$; Fig. $3 A, E, p=0.0003$ ) after induction. Chronic treatment of $F m r 1$ KO mice with rolipram $(n=7$ slices, 7 mice, open circles) abrogated the enhanced mGluR-LTD phenotype compared with vehicle-treated $F m r 1 \mathrm{KO}$ mice at $60 \mathrm{~min}$ (Fmr1 KO vehicle: $69.3 \pm 1.4 \%$; Fmr1 KO rolipram: 87.6 $\pm 1.9 \%$; Fig. 3D, $\left.{ }^{* *} p=0.001\right)$ and at 80 min (Fmr1 KO vehicle: $71.1 \pm 2.1 \%$; Fmr1 KO rolipram: $87.9 \pm 1.9 \% ;{ }^{* * *} p=0.0001$ ) after induction. $B$, Mean evoked fEPSP slopes $( \pm$ SD) are plotted at three different stimulus intensities. Synaptic responses at threshold, half-maximal, and maximal stimulus intensities between rolipram-treated Fmr1 KO mice ( $n=7$ slices, 7 mice, open circles) and interleaved age-matched vehicle-treated Fmr1 $\mathrm{KO}$ mice ( $n=5$ slices, 5 mice, filled squares) were not different. C, PPF, evoked as described in Figure 2, between rolipram-treated Fmr $1 \mathrm{KO}$ mice ( $n=7$ slices, 7 mice, open circles) and interleaved age-matched vehicle-treated $F m r 1 \mathrm{KO}$ mice ( $n=5$ slices, 5 mice, filled squares) was not different. Synaptic responses to paired stimulation were evoked at interstimulus intervals ranging from 15 to $100 \mathrm{~ms}$. Plotted are mean percentage facilitation ( \pm SD), as determined by calculating the ratio of the second fEPSP slope to the first fEPSP slope. D, E, DHPG-LTD in WT and Fmr 1 $K O$ mice treated with vehicle or rolipram at 60 or 80 min after induction. ${ }^{* *} p<0.001$ (two-way ANOVA). ${ }^{* *} p<0.0001$ (two-way ANOVA). §Significant difference between WT and Fmr1 KO mice on vehicle treatment $(p=0.0001)$ at $60 \mathrm{~min}$ and $(p=0.0003)$ at $80 \mathrm{~min}$. ${ }^{*}$ Significance with respect to vehicle treatment within the same genotype. The number above each bar indicates the $n$. 

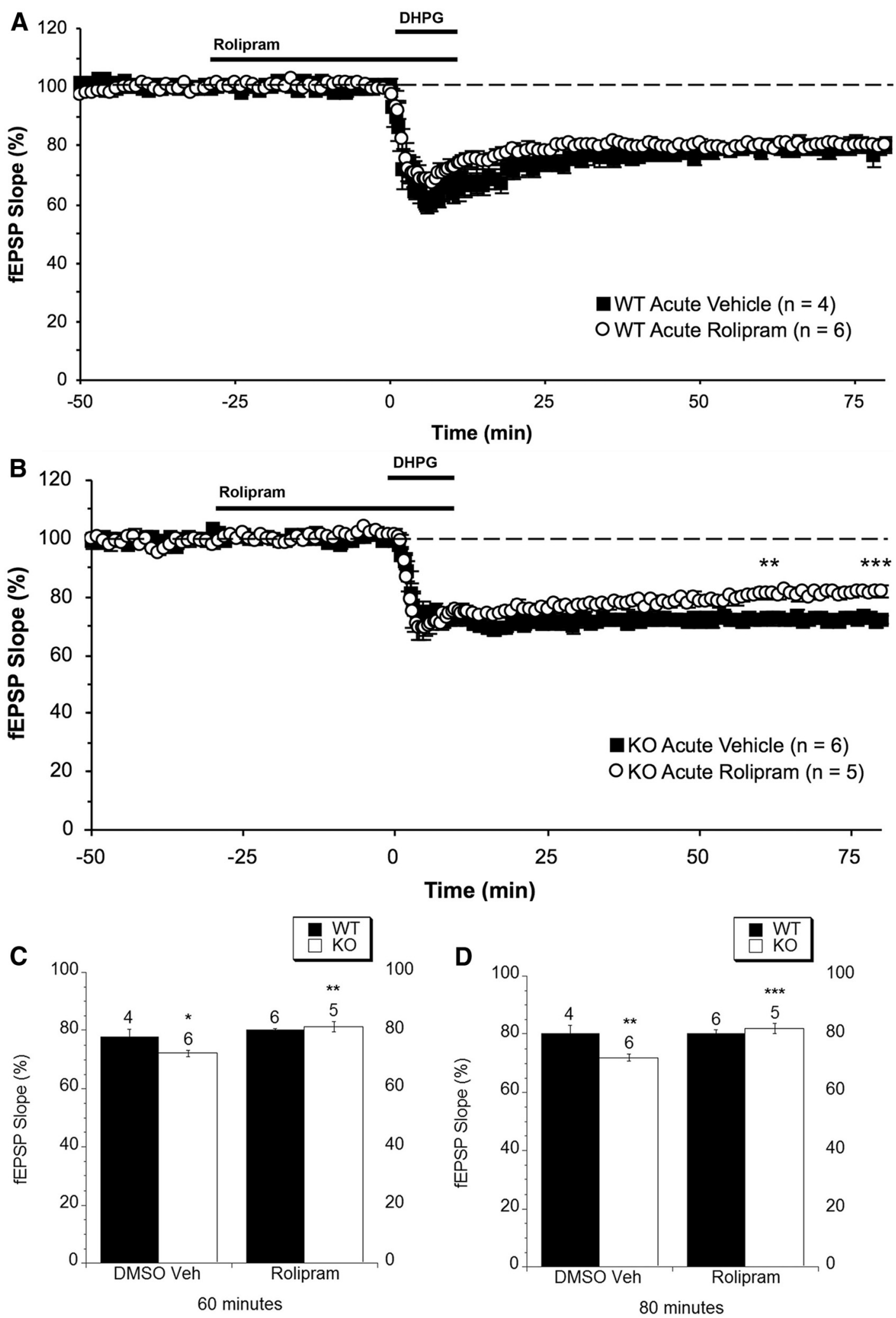

Figure 6. Differential effects of acute rolipram treatment in WT versus Fmr $1 \mathrm{KO}$ mice. $A, B$, Acute bath application of rolipram in WT mice. Plotted are average fEPSP slope values ( \pm SEM) as a percentage of average preinduction baseline values. $A$, WT mice were acutely treated with rolipram ( $n=6$ slices, 6 mice, open circles) or with DMSO vehicle alone ( $n=4$ slices, 4 mice, filled squares) at $60 \mathrm{~min}$ (WT acute vehicle: $77.9 \pm 2.4 \%$; WT acute rolipram: $80.1 \pm 0.7 \%$ ) and at $80 \mathrm{~min}$ (WT acute vehicle: $80.2 \pm 2.9 \%$; WT acute rolipram: $80.1 \pm 1.5 \%$ ) after induction. $\boldsymbol{B}$, Acute application of rolipram to slices from Fmr1 KO mice ( $n=5$ slices, 5 mice, open circles) compared with acute vehicle-treated $F m r 1 \mathrm{KO}$ mice $(n=6$ slices, 6 mice, filled squares) at 60 min ( $F m r 1 \mathrm{KO}$ acute vehicle: $72.2 \pm 1.0 \%$; Fmr1 KO acute rolipram: $81.3 \pm 1.9 \%$; Fig. $4 C, p=0.0002$ ) and at $80 \mathrm{~min}$ after induction (Fmr1 KO acute vehicle: $72.0 \pm 1.2 \%$; Fmr1 KO acute rolipram: $81.9 \pm 1.8 \%$; Fig. $4 D, p=$ 0.0001 ). C, D, DHPG-LTD in WT and Fmr1 KO mice treated with vehicle or rolipram at 60 or 80 min after induction. ${ }^{* *} p<0.001$ (two-way ANOVA). ${ }^{* * *} p<0.0001$ (two-way ANOVA). §Significant difference between WT and Fmr $1 K O$ mice on vehicle treatment $(p=0.02)$ at $60 \mathrm{~min}$ and $(p=0.0015)$ at $80 \mathrm{~min}$. ${ }^{*}$ Significance with respect to vehicle treatment within the same genotype. The number above each bar indicates the $n$. Acute rolipram treatment significantly reduces mGluR-LTD in Fmr1 KO mice; in contrast, no effect of treatment is seen in WT mice. 
hypoactive cAMP signaling or hyperactive cAMP signaling will lead to memory impairment. The classical example of this with regard to memory was first provided in Drosophila where the rutabaga mutation leads to hypoactive cAMP signaling and the dunce mutation leads to hyperactive cAMP signaling and both result in memory impairment. Consistent with this supposition, we found that acute treatment with rolipram had no effect on LTD in WT mice at $80.1 \pm 0.7 \%$ and $80.1 \pm 1.5 \%$ at 60 and 80 min after induction (Fig. $6 A, C, D$ ). Similar acute treatment with DMSO vehicle also had no effect on DHPG-induced mGluRLTD in WT mice, which is $77.9 \pm 2.4 \%$ and $80.2 \pm 2.9 \%$ of average preinduction baseline values at 60 and $80 \mathrm{~min}$ after induction (Fig. $6 A, C, D$ ). These finding suggest that, under this set of conditions, the signaling system may prevent overactive cAMP signaling from altering the magnitude DHPG-induced mGluRLTD in WT mice.

mGluR-LTD remained enhanced in Fmr1 KO mice upon bath application of DMSO vehicle at 72.2 $\pm 1.0 \%$ and $72.0 \pm 1.2 \%$ of baseline values at 60 and $80 \mathrm{~min}$ after induction (Fig. $6 B-D$ ). In contrast, acute bath application with rolipram eliminated the enhancement of mGluR-LTD, with fEPSP slope values of $81.3 \pm$ $1.9 \%$ and $81.9 \pm 1.8 \%$ relative to baseline at 60 and 80 min after induction (Fig. $6 B-D$ ). This demonstrated that acute increases in cAMP can restore mGluR-LTD to WT levels, indicating that there is a role for cAMP in the acute regulation of $\mathrm{mGluR}$-LTD in Fmr1 KO mice.

\section{Discussion}

Despite intellectual disability affecting $3 \%$ of the population, the pathognomonic cognitive impairments remain without clinical treatment at this time. This remains a large unmet medical need impairing the lives of afflicted patients, families, and caregivers and the health system as a whole with estimates for care over the course of a lifetime being $\$ 1.4$ million for intellectual disability and \$2.4 million for intellectual disability with comorbid autism spectrum disorder in the United States, highlighting the need for the development for potential treatments (Buescher et al., 2014). FXS is the most common cause of single gene-related intellectual disability and autism spectrum disorder. The overall objective of this work was to examine the efficacy of pharmacologically inhibiting PDE-4 activity to correct cognitive defects observed in the fly and mouse models of FXS.

\section{Rescue of memory in the Drosophila model of fragile X}

The Drosophila fragile X model recapitulates the most debilitating aspect of the disease in humans, namely, impaired cognitive function. In our further dissection of the proteins involved in the mGluR signaling cascade, we identified PDE-4 as a potential substrate whose inhibition may be beneficial in restoring proper intracellular signaling in the fragile X model (Fig. 1A). Based on our data and that of others on the $d f m r 1$ mutants, tissue culture work, studies of the mouse model, and samples from humans afflicted with FXS, we knew that cAMP levels are suppressed in flies, mice, and human cell culture models of FXS (Berry-Kravis and Sklena 1993; Berry-Kravis et al., 1995; Berry-Kravis and Ciurlionis 1998; McBride et al., 2005; Kelley et al., 2007). PDE-4 inhibition should increase cAMP signaling by preventing the breakdown of cAMP that is produced during synaptic stimulation. Indeed, we observed that rolipram treatment raises the levels of cAMP in $d f m r 1$ mutants (Fig. $1 B$ ). That fragile $\mathrm{X}$ flies treated acutely or chronically in adulthood with PDE-4 inhibitors, or with genetically reduced levels of PDE-4, demonstrated intact courtship-based immediate recall and short-term memory and olfactory-based learning, validates PDE-4 inhibition as a potential novel therapeutic target for the treatment of fragile X. Importantly, this effect was independent of rescuing the development malformation of the mushroom body (MB). This finding adds to the growing body of literature demonstrating that pharmacologic treatment initiated in adulthood may have efficacy for the treatment of cognitive disorders that are already present in childhood as was first demonstrated in animal models of fragile $\mathrm{X}$ and neurofibromatosis Type 1 in 2005 (Li et al., 2005; McBride et al., 2005; for review, see Raymond and Tarpey 2006; Walsh et al., 2008).

\section{Rolipram treatment effectively restored proper mGluR-LTD in the Fmr1 KO mice}

Because the treatment of the fly fragile X model with PDE-4 inhibitors rescued memory defects in courtship and classical olfactory conditioning, we wanted to explore whether the same strategy might work in the mouse fragile $\mathrm{X}$ model. Because of its proven reproducibility, the endophenotype of enhanced DHPGinduced mGluR-LTD in the CA1 region of the hippocampus was chosen to examine the effects of chronic treatment with rolipram.

Our initial experiments revealed that chronic rolipram treatment abrogated the enhanced DHPG-induced LTD endophenotype in Fmr1 KO mice, whereas it strengthened mGluR-LTD in WT mice. We subsequently investigated the role of cAMP in mGluR-LTD in WT mice using acute rolipram treatment and did not see any effect of acute rolipram treatment on DHPG-induced LTD. In contrast, when acute treatment with rolipram was performed in Fmr1 KO mice, there was a restoration of normal levels of mGluR-LTD. This indicates a role for cAMP signaling in DHPG-induced LTD that was previously not identified. Investigating the exact reasons for the different response of the WT mice to chronic versus acute treatment is rolipram treatment is beyond the scope of the current research endeavor. However, one reason this may occur is through compensation in the system. The neuronal signaling network is set up to maintain an optimal range for cAMP signaling in the brain (Sato et al., 2004). In the Fmr1 KO mice, cAMP levels are abnormally low after synaptic stimulation. Therefore, chronically raising cAMP levels into the normal range allows the system to reset a balance in cAMP signaling even after cessation of rolipram treatment, likely mediated through transcriptional changes. However, in the WT mice, chronic rolipram treatment likely increases cAMP signaling above the optimal range. Therefore, the system is likely attempting to compensate by dampening cAMP signaling during the duration of treatment with rolipram, and by the end of the 8 week treatment the system has likely reached a homeostasis to compensate for the artificially high cAMP levels through transcriptionally mediated changes. However, once the rolipram treatment has been removed, the system is continuing to dampen cAMP signaling leading to the enhanced LTD in the WT mice.

\section{Rolipram and other potential treatments for fragile $\mathrm{X}$}

Our data presented here fit well with recent data indicating that chronic mGluR antagonist treatment is also able to rescue memory deficits in the fragile X Drosophila model (McBride et al., 2005; Choi et al., 2010) as well chronic Group II mGluR antagonist treatment being able to restore proper mGluR-dependent LTD (Choi et al., 2011). Because Group II mGluRs are coupled predominantly to $\mathrm{Gi}$, thereby decreasing cAMP levels after synaptic stimulation, and to a lesser extent to $\mathrm{Gq}$, thereby activating InsP3R mediated calcium signaling, the case for a role of cAMP signaling in mGluR-dependent LTD seems well founded. Indeed, a precedent may be found in previous work that has indicated a 
role of Group II mGluRs receptor activation in reducing cAMP and inhibiting PKA during low-frequency stimulation of LTD as well as a role for Gi-coupled signaling during adenosine receptormediated LTD (Santschi et al., 2006; Bailey et al., 2008). Additionally, a rise in cAMP activity should promote PKA activity and antagonize GSK-3B activity (Fang et al., 2000; Li et al., 2000; Tanji et al., 2002) (Fig. 1A). Overactive GSK-3B activity has also been implicated in the pathogenesis of behavioral impairments in the Drosophila and mouse models of fragile X (McBride et al., 2005; Min et al., 2009; Mines et al., 2010; Yuskaitis et al., 2010a, b; Mines and Jope 2011; Franklin et al., 2014). Therefore, in addition to the cAMP pathway, GSK3B dysfunction may be corrected by PDE4 treatment. It is interesting to note that recently PDE- 4 was identified as a cargo mRNA of FMRP, which is canonically a translational repressor (Darnell et al., 2011).

In addition to increases in cAMP signaling by rolipram treatment, rolipram has also been demonstrated to inhibit expression and activity of matrix metalloprotease 9 (Martin-Chouly et al., 2004; Oger et al., 2005; Sánchez et al., 2005). Inhibition matrix metalloprotease 9 has been demonstrated to improve cognitive phenotypes in both mouse models of fragile X and Alzheimer's disease and has even shown efficacy in an open label trial in fragile X (Choi et al., 2007; Bilousova et al., 2009; Garcia-Alloza et al., 2009; Noble et al., 2009; Cuello et al., 2010; Paribello et al., 2010). Together, these results demonstrate the efficacy of pharmacologically inhibiting PDE-4 in the fly and mouse model of fragile X and identify, for the first time, PDE- 4 as a potential therapeutic target for fragile $\mathrm{X}$.

In conclusion, our work demonstrates that PDE-4 inhibition is a novel therapeutic target for the treatment of fragile X. Before this work, it has only recently been demonstrated that enhanced LTD in the fragile X model could be abrogated by chronic pharmacologic treatment (Choi et al., 2011). Equally as important is the demonstration that treatment in adulthood alone can rescue the phenotype, meaning that the phenotype is not irreversibly determined by pathogenic developmental circuitry. These findings urge the need for further exploration of PDE-4 inhibition as a potential therapy in fragile $\mathrm{X}$ patients and in animal models of fragile X. Additionally, this work is a stepping stone for the field to begin a further pharmacologic dissection of the pathogenic signaling leading to aberrant LTD in the fragile X model mouse, with the hope of these findings allowing the treatment of patients afflicted with fragile X.

\section{References}

Akins MR, Berk-Rauch HE, Fallon JR (2009) Presynaptic translation: stepping out of the postsynaptic shadow. Front Neural Circuits 3:17. CrossRef Medline

Bailey CP, Nicholls RE, Zhang XL, Zhou ZY, Müller W, Kandel ER, Stanton PK (2008) Galpha(i2) inhibition of adenylate cyclase regulates presynaptic activity and unmasks cGMP-dependent long-term depression at Schaffer collateral-CA1 hippocampal synapses. Learn Mem 15:261-270. CrossRef Medline

Banerjee P, Schoenfeld BP, Bell AJ, Choi CH, Bradley MP, Hinchey P, Kollaros M, Park JH, McBride SM, Dockendorff TC (2010) Short- and longterm memory are modulated by multiple isoforms of the fragile $\mathrm{X}$ mental retardation protein. J Neurosci 30:6782-6792. CrossRef Medline

Barad M, Bourtchouladze R, Winder DG, Golan H, Kandel E (1998) Rolipram, a type IV-specific phosphodiesterase inhibitor, facilitates the establishment of long-lasting long-term potentiation and improves memory. Proc Natl Acad Sci U S A 95:15020-15025. CrossRef Medline

Bear MF, Huber KM, Warren ST (2004) The mGluR theory of fragile X mental retardation. Trends Neurosci 27:370-377. CrossRef Medline

Berry-Kravis E, Ciurlionis R (1998) Overexpression of fragile X gene (FMR-1) transcripts increases cAMP production in neural cells. J Neurosci Res 51:41-48. CrossRef Medline
Berry-Kravis E, Hicar M, Ciurlionis R (1995) Reduced cyclic AMP production in fragile $\mathrm{X}$ syndrome: cytogenetic and molecular correlations. Pediatr Res 38:638-643. CrossRef Medline

Berry-Kravis E, Huttenlocher PR (1992) Cyclic AMP metabolism in fragile X syndrome. Ann Neurol 31:22-26. CrossRef Medline

Berry-Kravis E, Sklena P (1993) Demonstration of abnormal cyclic AMP production in platelets from patients with fragile X syndrome. Am J Med Genet 45:81-87. CrossRef Medline

Berry-Kravis E, Sumis A, Hervey C, Nelson M, Porges SW, Weng N, Weiler IJ, Greenough WT (2008) Open-label treatment trial of lithium to target the underlying defect in fragile X syndrome. J Dev Behav Pediatr 29:293302. CrossRef Medline

Bhogal B, Jongens TA (2010) Fragile X syndrome and model organisms: identifying potential routes of therapeutic intervention. Dis Model Mech 3:693-700. CrossRef Medline

Bilousova TV, Dansie L, Ngo M, Aye J, Charles JR, Ethell DW, Ethell IM (2009) Minocycline promotes dendritic spine maturation and improves behavioural performance in the fragile X mouse model. J Med Genet 46:94-102. CrossRef Medline

Bolduc FV, Bell K, Cox H, Broadie KS, Tully T (2008) Excess protein synthesis in Drosophila fragile $\mathrm{X}$ mutants impairs long-term memory. Nat Neurosci 11:1143-1145. CrossRef Medline

Bolduc FV, Tully T (2009) Fruit flies and intellectual disability. Fly (Austin) 3:91-104. CrossRef Medline

Buescher AV, Cidav Z, Knapp M, Mandell DS (2014) Costs of autism spectrum disorders in the United Kingdom and the United States. JAMA Pediatr 168:721-728. Medline

Byers D, Davis RL, Kiger JA Jr (1981) Defect in cyclic AMP phosphodiesterase due to the dunce mutation of learning in Drosophila melanogaster. Nature 289:79-81. Medline

Choi CH, McBride SM, Schoenfeld BP, Liebelt DA, Ferreiro D, Ferrick NJ, Hinchey P, Kollaros M, Rudominer RL, Terlizzi AM, Koenigsberg E, Wang Y, Sumida A, Nguyen HT, Bell AJ, McDonald TV, Jongens TA (2010) Age-dependent cognitive impairment in a Drosophila fragile X model and its pharmacological rescue. Biogerontology 11:347-362. CrossRef Medline

Choi CH, Schoenfeld BP, Bell AJ, Hinchey P, Kollaros M, Gertner MJ, Woo NH, Tranfaglia MR, Bear MF, Zukin RS, McDonald TV, Jongens TA, McBride SM (2011) Pharmacological reversal of synaptic plasticity deficits in the mouse model of Fragile X syndrome by group II mGluR antagonist or lithium treatment. Brain Res 1380:106-119. Medline

Choi Y, Kim HS, Shin KY, Kim EM, Kim M, Kim HS, Park CH, Jeong YH, Yoo J, Lee JP, Chang KA, Kim S, Suh YH (2007) Minocycline attenuates neuronal cell death and improves cognitive impairment in Alzheimer's disease models. Neuropsychopharmacology 32:2393-2404. CrossRef Medline

Cuello AC, Ferretti MT, Leon WC, Iulita MF, Melis T, Ducatenzeiler A, Bruno MA, Canneva F (2010) Early-stage inflammation and experimental therapy in transgenic models of the Alzheimer-like amyloid pathology. Neurodegener Dis 7:96-98. CrossRef Medline

Darnell JC, Klann E (2013) The translation of translational control by FMRP: therapeutic targets for FXS. Nat Neurosci 16:1530-1536. CrossRef Medline

Darnell JC, Van Driesche SJ, Zhang C, Hung KY, Mele A, Fraser CE, Stone EF, Chen C, Fak JJ, Chi SW, Licatalosi DD, Richter JD, Darnell RB (2011) FMRP stalls ribosomal translocation on mRNAs linked to synaptic function and autism. Cell 146:247-261. CrossRef Medline

Davis RL (1993) Mushroom bodies and Drosophila learning. Neuron 11:1-14. CrossRef Medline

Davis RL, Kiger JA Jr (1981) Dunce mutants of Drosophila melanogaster: mutants defective in the cyclic AMP phosphodiesterase enzyme system. J Cell Biol 90:101-107. Medline

Davis RL, Takayasu H, Eberwine M, Myres J (1989) Cloning and characterization of mammalian homologs of the Drosophila dunce+ gene. Proc Natl Acad Sci U S A 86:3604-3608. CrossRef Medline

Dockendorff TC, Su HS, McBride SM, Yang Z, Choi CH, Siwicki KK, Sehgal A, Jongens TA (2002) Drosophila lacking dfmrl activity show defects in circadian output and fail to maintain courtship interest. Neuron 34:973984. CrossRef Medline

Dölen G, Osterweil E, Rao BS, Smith GB, Auerbach BD, Chattarji S, Bear MF (2007) Correction of fragile X syndrome in mice. Neuron 56:955-962. CrossRef Medline 
Dudai Y, Jan YN, Byers D, Quinn WG, Benzer S (1976) dunce, a mutant of Drosophila deficient in learning. Proc Natl Acad Sci U S A 73:1684-1688. CrossRef Medline

Duerr JS, Quinn WG (1982) Three Drosophila mutations that block associative learning also affect habituation and sensitization. Proc Natl Acad Sci U S A 79:3646-3650. CrossRef Medline

Dujardin F (1850) Memoire sur le systeme nerveux des insectes. Ann Sci Nat Zool 14.

Fang X, Yu SX, Lu Y, Bast RC Jr, Woodgett JR, Mills GB (2000) Phosphorylation and inactivation of glycogen synthase kinase 3 by protein kinase $A$. Proc Natl Acad Sci U S A 97:11960-11965. CrossRef Medline

Franklin AV, King MK, Palomo V, Martinez A, McMahon LL, Jope RS (2014) Glycogen synthase kinase-3 inhibitors reverse deficits in longterm potentiation and cognition in fragile X mice. Biol Psychiatry 75: 198-206. CrossRef Medline

Garcia-Alloza M, Prada C, Lattarulo C, Fine S, Borrelli LA, Betensky R, Greenberg SM, Frosch MP, Bacskai BJ (2009) Matrix metalloproteinase inhibition reduces oxidative stress associated with cerebral amyloid angiopathy in vivo in transgenic mice. J Neurochem 109:1636-1647. CrossRef Medline

Gong B, Vitolo OV, Trinchese F, Liu S, Shelanski M, Arancio O (2004) Persistent improvement in synaptic and cognitive functions in an Alzheimer mouse model after rolipram treatment. J Clin Invest 114:1624-1634. CrossRef Medline

Gross C, Berry-Kravis EM, Bassell GJ (2012) Therapeutic strategies in fragile $\mathrm{X}$ syndrome: dysregulated mGluR signaling and beyond. Neuropsychopharmacology 37:178-195. CrossRef Medline

Hagerman PJ (2008) The fragile X prevalence paradox. J Med Genet 45: 498-499. CrossRef Medline

Hagerman R, Lauterborn J, Au J, Berry-Kravis E (2012) Fragile X syndrome and targeted treatment trials. Results Probl Cell Differ 54:297-335. CrossRef Medline

Henkel-Tigges J, Davis RL (1990) Rat homologs of the Drosophila dunce gene code for cyclic AMP phosphodiesterases sensitive to rolipram and RO 20-1724. Mol Pharmacol 37:7-10. Medline

Hou J, Kuromi H, Fukasawa Y, Ueno K, Sakai T, Kidokoro Y (2004) Repetitive exposures to nicotine induce a hyper-responsiveness via the cAMP/ PKA/CREB signal pathway in Drosophila. J Neurobiol 60:249-261. CrossRef Medline

Hou L, Antion MD, Hu D, Spencer CM, Paylor R, Klann E (2006) Dynamic translational and proteasomal regulation of fragile $\mathrm{X}$ mental retardation protein controls mGluR-dependent long-term depression. Neuron 51: 441-454. CrossRef Medline

Huber KM, Gallagher SM, Warren ST, Bear MF (2002) Altered synaptic plasticity in a mouse model of fragile X mental retardation. Proc Natl Acad Sci U S A 99:7746-7750. CrossRef Medline

Huber KM, Kayser MS, Bear MF (2000) Role for rapid dendritic protein synthesis in hippocampal mGluR-dependent long-term depression. Science 288:1254-1257. CrossRef Medline

Huber KM, Roder JC, Bear MF (2001) Chemical induction of mGluR5- and protein synthesis-dependent long-term depression in hippocampal area CA1. J Neurophysiol 86:321-325. Medline

Hwu WL, Wang TR, Lee YM (1997) FMR1 enhancer is regulated by cAMP through a cAMP-responsive element. DNA Cell Biol 16:449-453. CrossRef Medline

Impey S, McCorkle SR, Cha-Molstad H, Dwyer JM, Yochum GS, Boss JM, McWeeney S, Dunn JJ, Mandel G, Goodman RH (2004) Defining the CREB regulon: a genome-wide analysis of transcription factor regulatory regions. Cell 119:1041-1054. CrossRef Medline

Jacquemont S, Hagerman RJ, Hagerman PJ, Leehey MA (2007) Fragile-X syndrome and fragile X-associated tremor/ataxia syndrome: two faces of FMR1. Lancet Neurol 6:45-55. CrossRef Medline

Joiner MIA, Griffith LC (1997) CaM kinase II and visual input modulate memory formation in the neuronal circuit controlling courtship conditioning. J Neurosci 17:9384-9391. Medline

Kamyshev NG, Iliadi KG, Bragina JV (1999) Drosophila conditioned courtship: two ways of testing memory. Learn Mem 6:1-20. CrossRef Medline

Kandel ER (2001) The molecular biology of memory storage: a dialogue between genes and synapses. Science 294:1030-1038. CrossRef Medline

Kane NS, Robichon A, Dickinson JA, Greenspan RJ (1997) Learning without performance in PKC-deficient Drosophila. Neuron 18:307-314. CrossRef Medline
Kanellopoulos AK, Semelidou O, Kotini AG, Anezaki M, Skoulakis EM (2012) Learning and memory deficits consequent to reduction of the fragile $\mathrm{X}$ mental retardation protein result from metabotropic glutamate receptor-mediated inhibition of cAMP signaling in Drosophila. J Neurosci 32:13111-13124. CrossRef Medline

Keleman K, Krüttner S, Alenius M, Dickson BJ (2007) Function of the Drosophila CPEB protein Orb2 in long-term courtship memory. Nat Neurosci 10:1587-1593. CrossRef Medline

Kelleher RJ 3rd, Govindarajan A, Tonegawa S (2004) Translational regulatory mechanisms in persistent forms of synaptic plasticity. Neuron 44:59-73. CrossRef Medline

Kelley DJ, Davidson RJ, Elliott JL, Lahvis GP, Yin JC, Bhattacharyya A (2007) The cyclic AMP cascade is altered in the fragile $\mathrm{X}$ nervous system. PLoS One 2:e931. CrossRef Medline

Krueger DD, Bear MF (2011) Toward fulfilling the promise of molecular medicine in fragile X syndrome. Annu Rev Med 62:411-429. CrossRef Medline

Li M, Wang X, Meintzer MK, Laessig T, Birnbaum MJ, Heidenreich KA (2000) Cyclic AMP promotes neuronal survival by phosphorylation of glycogen synthase kinase 3beta. Mol Cell Biol 20:9356-9363. CrossRef Medline

Li W, Cui Y, Kushner SA, Brown RA, Jentsch JD, Frankland PW, Cannon TD, Silva AJ (2005) The HMG-CoA reductase inhibitor lovastatin reverses the learning and attention deficits in a mouse model of neurofibromatosis type 1. Curr Biol 15:1961-1967. CrossRef Medline

Liu ZH, Chuang DM, Smith CB (2011) Lithium ameliorates phenotypic deficits in a mouse model of fragile $\mathrm{X}$ syndrome. Int J Neuropsychopharmacol 14:618-630. CrossRef Medline

Malenka RC, Bear MF (2004) LTP and LTD: an embarrassment of riches. Neuron 44:5-21. CrossRef Medline

Martin-Chouly CA, Astier A, Jacob C, Pruniaux MP, Bertrand C, Lagente V (2004) Modulation of matrix metalloproteinase production from human lung fibroblasts by type 4 phosphodiesterase inhibitors. Life Sci 75 : 823-840. CrossRef Medline

McBride SM, Giuliani G, Choi C, Krause P, Correale D, Watson K, Baker G, Siwicki KK (1999) Mushroom body ablation impairs short-term memory and long-term memory of courtship conditioning in Drosophila melanogaster. Neuron 24:967-977. CrossRef Medline

McBride SM, Choi CH, Wang Y, Liebelt D, Braunstein E, Ferreiro D, Sehgal A, Siwicki KK, Dockendorff TC, Nguyen HT, McDonald TV, Jongens TA (2005) Pharmacological rescue of synaptic plasticity, courtship behavior, and mushroom body defects in a Drosophila model of fragile X syndrome. Neuron 45:753-764. CrossRef Medline

McBride SM, Choi CH, Schoenfeld BP, Bell AJ, Liebelt DA, Ferreiro D, Choi RJ, Hinchey P, Kollaros M, Terlizzi AM, Ferrick NJ, Koenigsberg E, Rudominer RL, Sumida A, Chiorean S, Siwicki KK, Nguyen HT, Fortini ME, McDonald TV, Jongens TA (2010) Pharmacological and genetic reversal of age-dependent cognitive deficits attributable to decreased presenilin function. J Neurosci 30:9510-9522. CrossRef Medline

McBride SM, Bell AJ, Jongens TA (2012) Behavior in a Drosophila model of fragile X. Results Probl Cell Differ 54:83-117. CrossRef Medline

Michel CI, Kraft R, Restifo LL (2004) Defective neuronal development in the mushroom bodies of Drosophila fragile X mental retardation $1 \mathrm{mu}-$ tants. J Neurosci 24:5798-5809. CrossRef Medline

Min WW, Yuskaitis CJ, Yan Q, Sikorski C, Chen S, Jope RS, Bauchwitz RP (2009) Elevated glycogen synthase kinase-3 activity in Fragile X mice: key metabolic regulator with evidence for treatment potential. Neuropharmacology 56:463-472. CrossRef Medline

Mines MA, Jope RS (2011) Glycogen synthase kinase-3: a promising therapeutic target for fragile X syndrome. Front Mol Neurosci 4:35. CrossRef Medline

Mines MA, Yuskaitis CJ, King MK, Beurel E, Jope RS (2010) GSK3 influences social preference and anxiety-related behaviors during social interaction in a mouse model of fragile X syndrome and autism. PLoS One 5:e9706. CrossRef Medline

Morales J, Hiesinger PR, Schroeder AJ, Kume K, Verstreken P, Jackson FR, Nelson DL, Hassan BA (2002) Drosophila fragile X protein, DFXR, regulates neuronal morphology and function in the brain. Neuron 34:961972. CrossRef Medline

Noble W, Garwood C, Stephenson J, Kinsey AM, Hanger DP, Anderton BH (2009) Minocycline reduces the development of abnormal tau species in models of Alzheimer's disease. FASEB J 23:739-750. CrossRef Medline 
Nosyreva ED, Huber KM (2006) Metabotropic receptor-dependent longterm depression persists in the absence of protein synthesis in the mouse model of fragile X syndrome. J Neurophysiol 95:3291-3295. CrossRef Medline

O'Kane CJ (2011) Drosophila as a model organism for the study of neuropsychiatric disorders. Curr Top Behav Neurosci 7:37-60. CrossRef Medline

Oger S, Méhats C, Dallot E, Cabrol D, Leroy MJ (2005) Evidence for a role of phosphodiesterase 4 in lipopolysaccharide-stimulated prostaglandin E2 production and matrix metalloproteinase- 9 activity in human amniochorionic membranes. J Immunol 174:8082-8089. CrossRef Medline

Paribello C, Tao L, Folino A, Berry-Kravis E, Tranfaglia M, Ethell IM, Ethell DW (2010) Open-label add-on treatment trial of minocycline in fragile X syndrome. BMC Neurol 10:91. CrossRef Medline

Pascual A, Préat T (2001) Localization of long-term memory within the Drosophila mushroom body. Science 294:1115-1117. CrossRef Medline

Raymond FL, Tarpey P (2006) The genetics of mental retardation. Hum Mol Genet 15:R110-R116. CrossRef Medline

Sánchez AJ, Puerta C, Ballester S, González P, Arriaga A, García-Merino A (2005) Rolipram impairs NF-kappaB activity and MMP-9 expression in experimental autoimmune encephalomyelitis. J Neuroimmunol 168:13-20. CrossRef Medline

Santschi LA, Zhang XL, Stanton PK (2006) Activation of receptors negatively coupled to adenylate cyclase is required for induction of long-term synaptic depression at Schaffer collateral-CA1 synapses. J Neurobiol 66: 205-219. CrossRef Medline

Sato T, Tanaka K, Ohnishi Y, Teramoto T, Irifune M, Nishikawa T (2004) Inhibitory effects of group II mGluR-related drugs on memory performance in mice. Physiol Behav 80:747-758. CrossRef Medline

Siegel RW, Hall JC (1979) Conditioned responses in courtship behavior of normal and mutant Drosophila. Proc Natl Acad Sci U S A 76:3430-3434. CrossRef Medline

Skoulakis EM, Grammenoudi S (2006) Dunces and da Vincis: the genetics of learning and memory in Drosophila. Cell Mol Life Sci 63:975-988. CrossRef Medline

Tanji C, Yamamoto H, Yorioka N, Kohno N, Kikuchi K, Kikuchi A (2002) A-kinase anchoring protein AKAP220 binds to glycogen synthase kinase3beta (GSK-3beta) and mediates protein kinase A-dependent inhibition of GSK-3beta. J Biol Chem 277:36955-36961. CrossRef Medline

Tessier CR, Broadie K (2012) Molecular and genetic analysis of the Drosophila model of fragile X syndrome. Results Probl Cell Differ 54:119-156. CrossRef Medline

Tully T, Quinn WG (1985) Classical conditioning and retention in normal and mutant Drosophila melanogaster. J Comp Physiol A Neuroethol Sens Neural Behav Physiol 157:263-277. CrossRef Medline

Walsh CA, Morrow EM, Rubenstein JL (2008) Autism and brain development. Cell 135:396-400. CrossRef Medline

Yan QJ, Rammal M, Tranfaglia M, Bauchwitz RP (2005) Suppression of two major Fragile X Syndrome mouse model phenotypes by the mGluR5 antagonist MPEP. Neuropharmacology 49:1053-1066. CrossRef Medline

Yin JC, Del Vecchio M, Zhou H, Tully T (1995) CREB as a memory modulator: induced expression of a dCREB2 activator isoform enhances longterm memory in Drosophila. Cell 81:107-115. CrossRef Medline

Yuskaitis CJ, Beurel E, Jope RS (2010a) Evidence of reactive astrocytes but not peripheral immune system activation in a mouse model of Fragile $X$ syndrome. Biochim Biophys Acta 1802:1006-1012. CrossRef Medline

Yuskaitis CJ, Mines MA, King MK, Sweatt JD, Miller CA, Jope RS (2010b) Lithium ameliorates altered glycogen synthase kinase- 3 and behavior in a mouse model of fragile X syndrome. Biochem Pharmacol 79:632-646. CrossRef Medline

Zars T, Fischer M, Schulz R, Heisenberg M (2000) Localization of a shortterm memory in Drosophila. Science 288:672-675. CrossRef Medline

Zhang YQ, Bailey AM, Matthies HJ, Renden RB, Smith MA, Speese SD, Rubin GM, Broadie K (2001) Drosophila fragile X-related gene regulates the MAP1B homolog Futsch to control synaptic structure and function. Cell 107:591-603. CrossRef Medline 